DOI: 10.19085 /journal.sijmas030501

\title{
Piercing the Veil's Effect on Corporate Human Rights Violations \& International Corporate Crime (Human Trafficking, Slavery, etc)
}

\author{
Joshua Konov \\ Wheeling IL, the USA/ Samokov, Bulgaria.
}

(1) Scholedge International Journal of Multidisciplinary \& Allied Studies (ISSN 2394-336X), Vol.03, Issue 05(2016) pg83-115. Published by: Scholedge R\&D Center [www.theSCHOLEDGE.org] [Email: editorial@thescholedge.org]

\begin{abstract}
Corporate limited liability laws (CLL) [the corporate veil (tCV)] is a major obstacle for implementation of UN and other covenants' prevention and jurisprudence ex ante and ex post facto Corporate Human Rights Violations (CHRV) and International Corporate Crime ( $\mathrm{ICrC}$ ). I.d. aggregates the inability of States and International Bodies to farther establish unified e.g., Lex Non Scripta common law with adjudicative and prescriptive jurisdiction and to apply the Lex Scripta civil and criminal laws to reduce infringements of the human rights and impunity in cases of corporate violations and criminal acts.
\end{abstract}

In this paper is argued that the change from Corporate Limited Liability (referred to as tCV) to Corporate Unlimited Liability (referred as PtCV) laws and thus criminalizing and adjudicating breaches of HR covenants and civil and criminal laws by corporate individuals, at prima facie should have a substantial preventative and sanctioning affect on reducing such $\mathrm{CHRV}$ and $\mathrm{ICrC}$. I.d., the unambiguous correlation between $\mathrm{CHRV}$ and $\mathrm{ICrC}$, (which in many occasions includes Human Trafficking, Slavery, Sex Trade, Child Labor, ext), which are accelerated by the 2001-2007

This research particularly separates equity ownership from corporate decision makers and management in regard PtCV, considering the last two liable for their CHRV and/or ICrC' mens rea (purpose, knowledge, recklessness, and negligence, however in "public welfare offenses, or vicarious Liability, or a defendant may be liable for international corporate crime absent any showing of mens rea), inchoate crime, and actus reus thus falling under the common, civil, criminal laws and torts. However the dividing corporate structures and seeking personal liability should depend from the corporate structure of directors, officers or managers' involvement in the CHRV and/or ICrC mens rea, inchoate crime and actus reus that will impute the PtCV' effect on their liability. Under modern corporate practice, it is the corporate executives who hold management functions, not the board members. Because the term managing model is now an inaccurate description (especially over the last 25 years).

Recessions through expanding global poverty and inequality. Piercing the Corporate Veil (PtCV) and Enhancing Business \& Contract Laws $(\mathrm{eBCL})$ would raise the market security thus needed to establish fair market competition benefiting Small and Medium Enterprises and Investors, which have become major global employers: action that would have a general positive market effect.

Id. Anyway with the current judicial practice, in most cases where there are grave personal injuries the court is willing to impute negligence to the parent company - especially where the subsidiary is thinly capitalized or appears to have been formed precisely to avoid liability. In contrast, courts are extremely reluctant to pierce the corporate veil in cases of purely pecuniary losses, namely where the creditors of a bankrupt corporation seek to reach the personal assets of the shareholders of the corporation. Eric Engle (2006). This is for the obvious reason that general financial liability of shareholders for all debts of a corporation would discourage investment in stocks with deleterious 
economic consequences. See, e.g. Krivo Indus. Supply Co. v. National Distillers \& Chem. Corp., 483 F.2d 1098, 1102 (5th Cir. 1973)

1. Abbreviations

Other International Bodies

Introduction

2. Corporations \& Human Rights

White Collar Crime

Economics of Crime

Employment and Crime

Globalization and Crime

Piercing Corporate Vail by the UN and other Organizations and Treaties

3. White Market \& Grey Market

4. General Piercing Corporate Veil to prevent from HRV

Approaches for prevention of Crime

5. Shrinking Markets effect on Human Rights

6. Conclusions

7. References

\section{Abbreviations:}

\section{AM Advanced Markets \\ ATCA Alien Tort Claims Act \\ ATS Alien Tort Statues \\ BOD Board of Directors}

CATSCA California Transparency in Supply Chains Act

CCR Center for Constitutional Rights

CHRV Corporate Human Rights Violations

CLL Corporate Limited Liability

CUL Corporate Unlimited Liability

DOJ US Department of Justice

DPA Differed Prosecution Agreement

EM Emerging Markets

EU European Union

EC European Commission

ECtHR European Court for Human Rights

ECHR European Convention for Human Rights

FDI Foreign Direct Investment

FIDH International Federation for Human Rights

FCPA Foreign Corrupt Practices Act

GP Guiding Principles

GRI Global Reporting Initiative

$\mathrm{ICrC}$ International Corporate Crime

ICC International Criminal Court

ILC International Law Commission

IACHR Inter-American Court of Human Rights

ICCPR International Covenant on Civil and Political Rights

ICESCR International Covenant on Economic, Social and Cultural Rights

ICTY International Criminal Tribunal for the Former Yugoslavia

ILO International Labor Organization

HR Human Rights

NGO Non-Governmental Organization

NPA Non-Prosecution Agreement

OECD Organization for Economic Co-operation and Development

$\mathrm{PtCV} \quad$ Piercing the Corporate Veil

RICO Racketeer Influenced and Corrupt Organizations Act

SME Small and Medium Enterprises 
SMI Small and Medium Investors

SRSG Secretary General's Special Representative

TNC Trans National Corporations

TVPA Torture Victim Protection Act

US United States

UN United Nations

UNODC United Nations Office for Drugs and Crime

UDHR Universal Declaration of Human Right

WCC White Collar Crime

\subsection{International Conventions and Bodies}

(Other then the Guiding Principles of SRSG and the mentioned in other sections)

1. International Convention on the Elimination of All Forms of Racial Discrimination (ICERD) notes the media's "particular responsibility" to refrain from disseminating prejudices, and recommends self-monitoring, including through codes of conduct in media organizations. The Committee has also said that "large business ventures" involved in projects affecting indigenous communities have a role to play in the "promotion" of human rights. However, this comment was only included in the Concluding Observations on Surinam in 2004, and later Concluding Observations have not contained similar recommendations. It is unclear whether ICERD would encourage that sort of responsibility more generally.

2. The International Covenant on Civil and Political Rights (ICCPR); The International Covenant on Economic, Social and Cultural Rights (ICESCR); CESCR has highlighted responsibilities for business enterprises not only in "respecting" rights but also in "realizing" rights. It has commented that, among other things, the private business sector should pursue its activities on the basis of codes of conduct conducive to the "respect of rights." CESCR has further directed that States should provide an environment facilitating third parties' fulfillment of any such responsibilities.

3. The International Convention on the Protection of the Rights of All Migrant Workers and Members of their Families (ICRMW);

4. The Convention on the Elimination of All Forms of Discrimination Against Women (CEDAW); - ICEDAW and the Committee on Migrant Workers (CMW) seem to generally limit their discussions on business 'responsibilities' or 'duties' to the responsibility to respect rights, in relation to private health care providers and recruitment agencies, respectively.

5. The Convention against Torture and Other Cruel, Inhuman or Degrading Treatment or Punishment (CAT);

6. The Convention on the Rights of the Child (CRC): Similarly, the CRC has highlighted responsibilities for business enterprises not only in "respecting" rights but also in "ensuring" rights. It has recognized that responsibilities to "respect" and "ensure" the rights of children extend in practice beyond the State and State controlled services to include, among others, nonState services, and organizations. It has directly addressed private actors, such as private service providers, the media, and banks, in recommending certain behavior such as the conduct of impact assessments, the incorporation of human rights protections into codes of conduct, and refraining from acts, which might jeopardize rights.

7. The International Convention on the Rights of Persons with Disabilities (ICRPD) and

8. The International Convention for the Protection of All Persons from Enforced Disappearances;

\subsection{Introduction}

This paper exposes the thesis that tCV confines states and international bodies (as Article 25(1) of the Rome Statute limits its jurisdiction to natural persons) in their effort to adjudicate corporate human rights violations ( $\mathrm{CHRV}$ ) and international corporate crime $(\mathrm{ICrC})$ perpetrated or complicit by corporations: their corporate directors, officers and risk managers, because behind any corporate structures are individuals taking decisions and executing these decisions. Unless the 
non-derogable jus cogens human rights, which under mounting public pressure have been contemplating changes in TNC policies worldwide in regards respect of such most egregious CHRV and avoiding of such ICrC (which includes white-collar crime WCC); however, the derogable human rights are legging way behind adjudication on the global marketplace. Hence, de jure and de facto, tCV is considered equally responsible and with the same measures actively preventing the implementation of Social and Environmental laws (such as nondiscrimination, health and safety, labor and employment rights, and the protection of the environment and cultural heritage) as a surrogate for human rights obligations.

The new accelerated globalization and rising productivity, contemporaneously causal of high tech rapid improvements and the break of the Soviet Block and China entering WTO, opens international borders to the TNC in a way unknown in history by giving TNC unambiguous access to markets, which combined with the high technologies and accumulations of capital allow TNC to move and outsource industrial production with higher then ever speed and proficiency. However, many markets advanced e.g. the US, the UK and emerging e.g. Greece, Portugal have been greatly undercut by this new developments not being able to perform "normally" by supporting employment and their fiscal reserves and policies. National debt has been accumulating in an accelerated way. The inability of states and international bodies to prevent from corporate direct and indirect $\mathrm{HRV}$ violations and $\mathrm{ICrC}$ has relation to these new market developments, therefore I consider PtCV as fundamental and a relatively "easy" less costly approach toward establishing fair market competition and reducing CHRV and ICrC. After PtCV approach is enhanced, the currently known WCC adjudication will evolve into $\mathrm{ICrC}$ adjudication by the corporate unlimited criminal liability on individual directors, officers, managers, and employees.

TNC have been using the new emerging market inequalities to pursue advantages. IIA's contracts between States and Stabilization Clauses pressing for exemptions from human rights and environmental laws and regulations, have been successful for TNC indeed, because of the disparity and lack of fiscal reserves experiencing by many host Developing States that have prompted governments to turn a blind eye on the CHRV and $\mathrm{ICrC}$ issues. To avoid laws and regulations, TNC have been relying also on the tCV giving impunity to the decision making corporate individuals personal for inflicted human rights violations and broken environmental, social, and cultural covenants, tax evasion, money laundering, human trafficking, ext..

The globalization aggregated by the 2001-07 Recessions has increased poverty and unemployment, and has not helped most emerging markets (exceptions as China and in certain aspect Brazil and India) to close on the frontiers $1 / \mathrm{f}$ noise as it was "predicted" by the "a priory" neo-liberal production based economics, it (the globalization) has opened the doors to greatest inequality, which could not be kept under lead because of the Internet and the informational access by many that inequality has been steering unrest and finally brought the terror, e.g. the September 11, and the following wars in Iraq and Afghanistan, the latest revolutions in the Middle East and North Africa, the public protests in Athens, Parish, Rome, ext; i.d. the overall negative affect on the fight against CHRV and WCC, a substantial setback in Human Rights Protection, and a setback in Human Civilization overall!

According to Janie Chuang, a professor at American University Washington College of Law, trafficking cases are a result of "labor migration gone horribly wrong in our globalized economy" (Chuang, 2006, p. 138). The increase in movement between nations has led to more opportunities for trafficking and exploitation. Workers, often in great need of employment, can easily fall victim as their desperation leads them to situations of vulnerability. Bridget O'Riordan (2009). Under current conditions of austerity measures and budget cuts individual human right mostly of the bottom levels of the markets and international crime are grossly undermined. National debt and lack of expansion of many markets and parts of markets have accelerated the diminishing of the middle class, the widening income gap, and expanding genuine poverty that process was greatly accelerated by the 2001-2007 recessions.

Hence, many individuals chose informal market activities including criminal enterprises of human trafficking growing into international crime. In this paper, corporate veil is directly related to 
expanding crime affecting grossly human rights. The recessions and accelerated market globalization and rising productivities are generally related to the shrinking markets, therefore these are directly related to international crime and the consequential human rights violations. Very much the same affect these new market developments have on international terrorism providing market initiatives for recruitment and ideological motivation. National security could be only improved if markets stop shrinking so a better market system of economics must be used to manage consistent market development by engaging more individuals in productive ways.

"The (Anti CHRV) framework rests on three pillars: the State duty to protect against human rights abuses by third parties, including business, through appropriate policies, regulation, and adjudication; the corporate responsibility to respect human rights, which in essence means to act with due diligence to avoid infringing on the rights of others; and greater access by victims to effective remedy, judicial and nonjudicial. The three pillars are complementary in that each supports the others." United Nations Human Rights Council (2009), States are entailed to ensure prevention of the third party HRV. However, the tCV compiled with the growing fiscal shortages and shrinking markets contemporaneously causal of the last recessions greatly interfere with states actual adjudication of the HR covenants already accepted by the UN.

A shift away from the state-centered focus of international law (as it suggests a legal personality of TNC, a development that can be argued to already be under way. The current direct international responsibilities on TNC are however of a non-legal character. J. Oloka-Onyango and Deepika Udagama (2000), Panitch, Leo, James H. Mittelman (1996). Non-binding initiatives could in a worst case scenario serve as an excuse to refrain from engaging in efforts to work towards a legal framework. In such cases the soft approach itself becomes a smoke screen for hiding from demands of compliance.

IIA's and stabilization clauses, corruption and weak laws, ext contribute to the corporate impunity and prevent from jurisprudence in many cases of CHRV, and in the beginning of all is the tCV depersonalization where the Torts (such as ATCA), Mandatory, ECHR and other laws apply extraterritorially only when gross jus cogens CHRV could be proven in the court of laws, while many legal and regulatory technicalities obscure jurisprudence in many CHRV and ICrC. The US Supreme Court does imply that by ATCA jus cogens extraterritorial claims will be heard and that they may also be the only claims it hears. Sosa v. Alvarez-Machain, 124 S.Ct. 2739 (2004). Historically, under ATCA and TVPA only jus cogens extraterritorial HRV claims are adjudicated.

In all it would seem then that a purely self-regulatory approach can not be relied upon if the goal is to ensure corporate responsibility. For that purpose self-regulation must fall within a stricter framework.

An important aspect of advocating individual criminal responsibility is the relationship of individual liability to the corporate entity. Although individuals can be criminally responsible for certain human rights violations, the question arises how the status as company employee or director relates to that responsibility. Viljam Engström (2002)

In the US Federal Criminal Laws (enhanced by the Sarbanes-Oxley Act) with Sentencing Guidelines through its Federal Criminal Code: Mail and Wire Fraud, Securities Fraud and Obstruction of Justice (obstructing a federal investigation of "any matter" and specifically includes bankruptcy proceedings, and provision requires "any accountant" to maintain audit documents and workpapers for five years), others are the general federal aiding and abetting statute, ext i.e. in the US the pierce the corporate veil and CUL that are well applying to sanction individual violators by the exposure of corporate managers and directors to civil and criminal laws. These ex post facto criminal laws could be well improved by an additional PtCV that by itself is ex ante preventive approach that also exposes corporate managers and directors to injunctions of all civil and general criminal laws and sanctions. While the International jurisprudence on CHRV and ICrC will be enhanced by adapting the US laws and will be enforced by PtCV. 
The system of corporate veil is pro big business and big market investors, however because of the improving high technologies in communications and manufacturing additionally aggregated by fast industrialization of China and the moving and outsourcing of industrial production from the US and other AM it has prompted high unemployment, high deficit and rising national debt. The transnational corporations (TNC) have not had the capabilities to expand and maintain needed national and global employment to balance market demand-to-supply, thus market processes have reduced profitability of the US and some other AM establishing shrinking and unbalanced market conditions, which allowed the 2001-07 recessions to additionally crash the system of market balance and invoke great upheaval to affect almost the entire world. Joshua Konov, (September 30, 2011)

\section{Corporate Human Rights Violations (CHRV) \& International Corporate Crime (ICrC)}

TNC are alleged to have been involved in-or were found culpable for - child labor(1), forced labor(2), torture(3) and violations of the rights to life and security of person(4), abuses to the right to information(5), labor rights abuses(6), gender discrimination(7), severe impacts to human health(8), and abuses of indigenous peoples rights(9). Other labor-related claims have been brought against corporations for human trafficking, including a case filed on behalf of Nepali laborers trafficked to Iraq against an American contractor, Kellogg Brown \& Root for its own acts and that of its subsidiary.

(1) See (1) International Labor Rights Forum (ILRF), Firestone Rubber \& Latex Company: Prospering from Child Labor and Enslavement in Liberia, Jamie Menutis (4 Dec. 2007) available at http://www.laborrights.org/stop-childlabor/stop-firestone/news/11244 (Liberians file class action suit under ATS against Firestone claiming forced child labor); (2) Germanwatch, Coalition against Bayer Dangers and Global March against Child Labor, Organization for Economic Cooperation and Development (OECD) Complaint Against Bayer because of Child Labor in India, Current Investigation: Children die due to poisoning by pesticides at Cotton Seed farms in India (11 Oct. 2004)

http://www.germanwatch.org/presse/2004-10-11e.htm (Emergent Genetics and Monsanto allegedly responsible for child labor in Indian cottonseed farms); and (3) Human Rights Watch (HRW), Turning a Blind Eye: Hazardous Child Labor in El Salvador's Sugarcane Cultivation (Jun. 2004), available at

http://www.hrw.org/reports/2004/elsalvador0604/elsalvador0604.pdf (Coca-coca allegedly uses sugar from an El Salvadorian mill supplied with sugarcane from child labor plantations).

(2) See EarthRights International (ERI), Supplemental Report: Forced Labor along the Yadana and Yetagun

Pipelines, available at http:/www.earthrights.org/files/Reports/supp.pdf (Unocal allegedly responsible for forced labor conscripted by military units in Burma pipeline projects).

(3) See (1) Human Rights First, Private Security Contractors at War, Ending the Culture of Impunity (2008), available at http://www.humanrightsfirst.info/pdf/08115-usls-psc-final.pdf (Private security contractors are not held criminally responsible by the Department of Justice for wounding and killing innocent civilians, as well as other excessive acts of violence and aggression); (2) Center for Constitutional Rights, Current Cases: Saleh v. Titan, available at http://www.ccrjustice.org/ourcases/current-cases/saleh-v.- titan (Class action lawsuit brought by about 250 Iraqi plaintiffs against Titan International and $\mathrm{CACl}$ International Inc for committing torture and other illegal acts of violence against detainees at various facilities including Abu Ghraib prison); (3) Earth Rights International, Factsheet: What Happened at Parabe?", available at http://www.earthrights.org/legalrelated/factsheet_what_happened_at_parabe.html (Chevron's Nigerian subsidiary participated in shooting, murder and torture of Nigerian villagers involved in an environmental protest against the company); (4) Cohen, Milstein, Hausfeld and Toll, International Human Rights Cases, ExxonMobil - Aceh, Indonesia, Doe v. ExxonMobil, available at http://www.cmht.com/cases_exxonmobilaceh.php (Eleven Indonesian citizens filed lawsuit against ExxonMobil for contracting security guards from the Indonesian military to commit kidnapping, 
torture and murder); and (5) Earth Rights International, EarthRights International Launches New Law Suit Against Chiquita for Funding, Arming, and Supporting Colombian Terrorists (17 Jul. 2007), available at http://www.earthrights.org/legalpr/eri_launches_lawsuit_against_chiquita.html (Federal class-action lawsuit charging Chiquita Brands International, Inc., with funding and arming known terrorist groups in Colombia in order to sustain its profitable control of Colombia's banana growing regions starting in the mid 1990s).

(4) See (I) Human Rights Watch, "Race to the Bottom", Corporate Complicity in Chinese Internet Censorship, Volume 18, No. 8(c) (2006), available at http://www.hrw.org/reports/2006/china0806/china0806web.pdf (China's ongoing Internet censorship being aided by corporate companies such as Yahoo!, Google, Microsoft and Cisco); (II) People's Republic of China, State Control of the Internet in China available at http://www.amnestyusa.org/document.php?lang=e\&id $=50 A 38 A 55 E B 758 C 0 C 80256 C 72004773 C D$

(Chinese authorities have implemented several regulations restricting freedom of expression and circulation of information); (III) Justice Initiative, ARTICLE 19, Libertad de Información Mexico, Asociación Civil, Instituto Prensa y Sociedad (IPYS) of Peru and Access Info Europe. Amicus brief (Brief presented before the IACtHR, Case No. 12108, Marcel Claude Reyes and others v. Chile, in Mar. 2006), available at

http://www.justiceinitiative.org/db/resource2?res id=103162 (Amicus brief asking the InterAmerican Court of Human Rights guarantees a general right of citizens to access information held by public authorities, and that Chile must improve its law regarding access to information); (IV) Petición de Caso ante la Comisión Inter-Americana de Derechos Humanos - Comunidad de La Oroya, (Dec. 2006), available at http://www.earthjustice.org/library/legal_docs/human-rights-petition-onla-oroya-to-iachr.pdf at 61 (Petition made to the Inter-American Court of Human Rights to ask Chile to comply with standards set in the American Convention of Human Rights); and (V) Baby Milk Action, Help the Philippines stand up to company bullying at http://www.babymilkaction.org/CEM/cemnov06.html (Baby food companies in Philippines mislead consumers).

(5) See (I) War on Want (WoW), ASDA Wal-Mart, the Alternative Report (Sep. 2005), available at http://www.waronwant.org/download.php?id $=369$ Rights of workers in Asda Wal-Mart stores increasingly violated due to costcutting); Clean Clothes Campaign (Europe), Oxfam Community aid Abroad (Australia), Oxfam Canada, Global Exchange (USA) and the Maquila Solidarity Network (Canada), We are not machines: Nike and Adidas workers in Indonesia (Mar. 2002), available at http://www.cleanclothes.org/documents/we_are_not_machines.pdf (Report discussing lack of improvement in working conditions in sport shoe factories producing for Nike and Adidas); (III) War on Want, Coca-Cola, The Alternative Report (Mar. 2006) at 8-9, available at http://www.waronwant.org/downloads/cocacola.pdf (Exposes Coca-Cola's adoption of anti-union tactics and its' involvement in death and disappearances of trade union activists across the globe); (IV) Gladys Manzanerez Tercero, Zenayda Torrez Aviles, Harling Bobadilla, and Felix Rosales Sanchez v. C\&Y Sportswear, Inc., Nien Hsing Textile Co., Ltd. and Chanted Garments, S.A., Complaint, available

http://www.nlcnet.org/campaigns/archive/sweatingforkohls/history.shtml\#court_complaint (C\&Y Sportswear officials and their subordinates were involved in attacks and intimidation against union leaders in Nicaragua); (V) Terry Collingsworth, Summary of International Labor Rights Fund Cases Under the Alien Torts Claims Act American Civil Liberties Union (ACLU) International Civil Liberties Report (2003), available at http://www.sdshh.com/ICLR/ICLR_2003/16_Collingsworth.pdf (Guatemalan trade union leaders brought case under Alien Tort Claim Act against Fresh Del Monte Produce Inc for complicity in security forces' execution of human rights violations); (VI) Doe v. Chiquita Brands Official Complaint (2007), available at http://www.earthrights.org/cbi_final_complaint.signed.pdf (Plaintiffs brought class action suit against Chiquita Brands International Inc for arming and supporting paramilitary groups that targeted and killed banana workers and trade unionists); and (VII) Global Policy Forum, DaimlerChrysler Sued Over Alleged Argentine Abuses, Pablo Bachelet (14 Jan. 2004), available at http://www.globalpolicy.org/intljustice/atca/2004/0114daimler.htm

(DaimlerChrysler AG was sued over role in disappearance and torture of union leaders and Mercedes-Benz plant workers in the suburbs of Buenos Aires). 
(6) See (I) Equal Rights Advocates, 6 Women Sue Wal-Mart, Charging Bias, Reed Abelson (20 Jun. 2001), available at http://www.equalrights.org/media/nytimes_walmart.asp (Six female employees file lawsuit against Wal-Mart for engaging in widespread discrimination against women); (II) The New York Times, Limbo for US Women Reporting Iraq Assaults, James Risen (13 Feb. 2008), available http://www.nytimes.com/2008/02/13/world/middleeast/13contractors.html?_ $r=1 \&$ oref=slogin

Female Ohio resident employed as a military contractor in Iraq accuses KBR Inc workers of sexual assault and harassment of women); (III) International Labor Rights Forum, Rights for Working Women Campaign, Sexual Harassment in the Workplace: A Report from Field Research in Thailand, Ubon Kompipote (Jun. 2002), available at http://www.laborrights.org/files/Thailand.pdf (A research study conducted in Thailand revealed that women workers in export industries in Thailand endure violent sexual abuse and discrimination); and (IV) Human Rights Watch, No Guarantees: Sex Discrimination in Mexico's Maquiladora Sector (1996), available at http://hrw.org/reports/1996/Mexio896.htm (Women working in Mexico's maquilas are required to have pregnancy tests done as a condition for employment, and can be dismissed or denied work if pregnant).

(7) See (I) Terra de Direitos, Fumo: servidão moderna e violação de direitos humanos, Guilherme Eidt Gonçalves de Almeida, (Curitiba: 2005), available at http://www.terradedireitos.org.br/wpcontent/uploads/2008/02/livrofum01.pdf (Addresses misuse of pesticides and effect on health of farmers); and (II) Germanwatch, Coalition against Bayer Dangers and Global March against Child Labor, Organization for Economic Cooperation and Development (OECD) Complaint Against Bayer because of Child Labor in India,

Current Investigation: Children die due to poisoning by pesticides at Cotton Seed farms in India (11 Oct. 2004), available at http://www.germanwatch.org/presse/2004-10-11e.htm (Children exposed to pesticides while working on cottonseed farms dying).

(8) For detailed descriptions of each of these incidents involving TNC, see ESCR-Net, "Collective Report on Business and Human Rights: Submission to the $8^{\text {th }}$ Session of the United Nations Human Rights Council," June, 2011

\section{PART I - OVERVIEW OF THE Findings}

- Corporations are alleged to impact the full range of human rights (see below for the list of rights impacted)-including civil and political rights; economic, social and cultural rights; and labor rights

\begin{tabular}{|c|c|c|c|}
\hline \multicolumn{2}{|l|}{ Freedom of association } & \multicolumn{2}{|c|}{ Right to equal pay for equal work } \\
\hline \multicolumn{2}{|c|}{$\begin{array}{l}\text { Right to organize and participate in collective } \\
\text { bargaining }\end{array}$} & \multicolumn{2}{|c|}{ Right to equality at work } \\
\hline \multicolumn{2}{|l|}{ Right to non-discrimination } & \multicolumn{2}{|c|}{ Right to just and favorable remuneration } \\
\hline \multicolumn{2}{|c|}{ Abolition of slavery and forced labor } & \multicolumn{2}{|c|}{ Right to a safe work environment } \\
\hline \multicolumn{2}{|l|}{ Abolition of child labor } & \multicolumn{2}{|c|}{ Right to rest and leisure } \\
\hline \multicolumn{2}{|l|}{ Right to work } & \multicolumn{2}{|c|}{ Right to family life } \\
\hline \multicolumn{4}{|c|}{ Non-Labor Rights Impacted } \\
\hline $\begin{array}{l}\text { Right to life, liberty and } \\
\text { security of the person }\end{array}$ & \multicolumn{2}{|c|}{ Right of peaceful assembly } & $\begin{array}{l}\text { Right to adequate an standard of } \\
\text { living (including food, clothing, and } \\
\text { housing) }\end{array}$ \\
\hline $\begin{array}{l}\text { Freedom from torture or } \\
\text { cruel, inhuman or } \\
\text { degrading treatment }\end{array}$ & \multicolumn{2}{|c|}{ Right to marry and form a family } & $\begin{array}{l}\text { Right to physical and mental health; } \\
\text { access to medical services }\end{array}$ \\
\hline $\begin{array}{l}\text { Equal recognition and } \\
\text { protection under the law }\end{array}$ & \multicolumn{2}{|c|}{$\begin{array}{l}\text { Freedom of thought, conscience } \\
\text { and religion }\end{array}$} & Right to education \\
\hline Right to a fair trial & \multicolumn{2}{|c|}{$\begin{array}{l}\text { Right to hold opinions, freedom } \\
\text { of information and expression }\end{array}$} & $\begin{array}{l}\text { Right to participate in cultural life, the } \\
\text { benefits of scientific progress, and } \\
\text { protection of authorial interests }\end{array}$ \\
\hline Right to self-determination & \multicolumn{2}{|c|}{ Right to political life } & Right to social security \\
\hline Freedom of movement & \multicolumn{2}{|l|}{ Right to privacy } & \\
\hline
\end{tabular}

The old way of slavery was that the boss really owned you, but now, legal recruiters and employers work in tandem to deceive workers who, vulnerable and isolated in a strange culture, are forced to accept harsh terms. It is in that context that you have endemic forced labor today (Bauer, 2007, p.23) Forced labor is fundamentally the result of a significant power disparity that 
exists between employers and their workers. This power disparity derives primarily from two sources: deceitful recruitment practices by labor recruiters in the countries of origin and the accumulation of debt by the workers themselves prior to arrival in the United States. The power disparity experienced by any victim of human trafficking creates the atmosphere of oppression necessary to maintain the abusive relationship (Bridget O'Riorda 2010).

In sum, the presence of all sectors and regions in the allegations supports the need for all corporate actors to consider the human rights implications of their activities. Moreover, the study indicates that the subject of this consideration should not be a short-list of rights but actually the full range of human rights. In addition, given the number of allegations of indirect abuse, firms should also consider the human rights records and activities of those with whom they have relationships-the allegations show that stakeholders where it contributes to or benefits may hold a firm accountable from third party abuses. (Michael Wright, A Survey of the Scope and Patterns of Alleged Corporate-Related Human Rights Abuse*2008)

There are a few principal mechanisms that have been used for compelling in particular corporate conduct:

- Some States actions against $\mathrm{CHRV}$ and ICrC that apply extraterritorially through legislation and judicial enforcement - e.g. are the US ATCA Alien Tort Claims Act (However, last September, Kiobel v. Royal Dutch Petroleum a split panel of the U.S. Court of Appeals for the Second Circuit held that the statute does not apply to corporations, but only to individuals), and the Foreign Corrupt Practices Act (FCPA), Torture Victim Protection Act (TVPA); The U.S. Department of Justice (DOJ) recently established a new Human Rights and Special Prosecutions Section of the Criminal Division tasked with enforcing these statute, overall, however, the U.S. has no general statutes that require U.S. businesses to observe internationally recognized human rights. European Convention for Human Rights, The United Kingdom's Bribery Act 2010, The Dodd-Frank Wall Street Reform and Consumer Protection Act of 2010, The Consumer Protection from Unfair Trading Regulations 2008, CATSCA the California Transparency in Supply Chains Act e.g.; A variety of national and state-level statutes generally prohibit businesses from practices such as racial discrimination and toxic pollution, for example, but these statutes often do not apply to such abuses abroad and/or do not incorporate the full spectrum of internationally-recognized human rights standards; The forum non conviniens and the very complex legal procedures are used by the US courts to actually let TNC committing CHRV and ICrC avoid justice. Other example, unless Canada's State Immunity Act is amended to create a general "torture" or "human rights abuse" exception, or Canadian federal legislation akin to the U.S. ATS, is enacted, the only viable alternative for imposing corporate liability against human rights abuses abroad appears to be the "forum of necessity" exception to the reformulated "real and substantial connection" test in Van Breda. And Ext.

- Some International actions e.g. starting from the Nuremberg's trails, the International Criminal Court (ICC), the UNODC, then the International Criminal Tribunal for Yugoslavia (ICTY), etc;

- The raising public awareness that can prompt shareholders and the public in general to insist and implement requirements for jurisprudence preventing CHRV and corporate impunity, which practice has been growing lately in the US and EU.

Currently, international human rights standards do not create binding legal obligations on TNC and state law fiduciary duty standards do not compel corporate Boards of Directors to act in furtherance of international human rights. Based on the current non-binding state of international law and well-established fiduciary duty principles, it appears that a claim against directors for a breach of fiduciary duty based solely on a corporate violation of international human rights standards (without a violation of law) is unlikely to succeed. (Law firm of Fried, Frank, Harris, Shriver \& Jacobson LLP, 2007).

In order to combat impunity for the crimes of genocide, war crimes, crimes against humanity, torture and forced disappearances, certain international treaties impose on all States parties to the relevant instruments - and, arguably, even on other States, on the basis of customary 
international law - an obligation to establish their jurisdiction over these crimes, even when they are committed abroad. However, this obligation concerns the prosecution for international crimes not of corporations, but of natural persons having committed or participated in such crimes. The implications as regards extraterritorial jurisdiction exercised over legal persons are unclear.

However, the Universal Declaration states that "every individual and every organ of society, keeping this Declaration constantly in mind, shall strive by teaching and education to promote respect for these rights and freedoms and by progressive measures, national and international, to secure their universal and effective recognition and observance..." does not exclude TNC from being obliged by covenants. The Adam Smith "invisible hand" is far from matching corporate and HR interests when TNC consist of individuals taking decisions, which in some occasions break human rights, or commit ICrC or are complicit with such, so to consider TNC naturally responsible is incomprehensible and is used to elude jurisprudence.

The TNC secrecy (to its opponents) or confidentiality (to its supporters) has its roots in the commercial arbitration process, which was the forerunner to the investor-state process. As the same rules were generally simply applied across the types of arbitrations, the confidentiality rules of commercial law became the norm for investor-state arbitration. However, there is widespread recognition that investor-state cases raise issues that are very different from commercial arbitration, and that these issues require the weighing of public interests as well as private ones. No other democratically based judicial process involving public issues and the public welfare is, it is submitted, as devoid of the basic guarantees of public access and accountability as the investorstate arbitration process. In many instances, shell corporations are being established in a state with a BIT with the intended host state when the real state of origin of the investor does not have one with that host state. (Howard Mann for the SRSG 2008)

The Guiding Principles (GP) for the Implementation of the U.N. 'Protect, Respect and Remedy' Framework by SRSG John G. Ruggie June, 2011, which accommodates in itself the soft adjudication approach used by the UN after the collapse in 2003 of the New International Economic Order (NIEO) replaced "to promote, secure the fulfillment of, respect, ensure respect of and protect human rights" direct TNC adjudicational approach.

The final version GP (16 June 2011) requires States as primary adjudicators and request TNC to prevent from and take responsibility for CHRV even when host States do not have proper CHRV adjudications. (The similar to the GP approach could be considered the anti tobacco public health approach that has been very effective in the $A M$ and even globally, however it confronted the tobacco industry only; unless, in the case of Global fight against CHRV such public health approach must confront transnational businesses in general in a greatly complex global market environment. With all due respect to Prof. Ruggie for his long-term contribution to the CHRV fight, the adequate jurisprudence in case of CHRV on the global markets could be achieved only by unified adjudication of TNC and the corporate decision makers and managers with applying civil and criminal laws jurisprudence). "Voluntary initiatives that invite and encourage corporate disclosure on non-financials (including human rights performance) have been instrumental in developing non-financial disclosure practice. But such initiatives have not been successful in mainstreaming corporate disclosure on non- financial (again including human rights performance)". Response to GP from Global Reporting Initiative on 27 Jan 2011.

Even the UN covenants are clear of what and when CHRV occurs, "the extension of extraterritorial jurisdiction is already quite developed in practice, in such areas as crimes under international law, financing of terrorism, corruption and bribery, human trafficking, sex tourism, and other human rights concerns" neither the ICC nor the states jurisprudence are ready to take on many cases especially when these ref. derogable HRV. (Because these domestic laws are some of the most common means of implementing International human rights obligations in regulating business activity, the whole system of national covenants that must grow into international on protecting against human rights violations does not perform appropriately contemporaneously causal of the corporate veils and the traditional business apprehension of IIA, stabilization clauses, and BIT contracts mostly between Advanced Markets - TNC and Emerging Markets - SME, which market 
conditions have become farther advantageous for the TNC because the 2007 Recessions emerging markets damages.

The fundamental methods used to fight Corporate Human Right Violations (CHRV) and constantly enhanced and improved by the UN, their commissions and SRSG, NGO and individual for countries torts and organizations are concluding into United Nation Charter of GP from 16 June 2011: $:$

a. Enhancing requested to the States implementations ante HRV laws;

b. Requiring TNC due diligence to avoid HRV;

c. Enhancing corporate responsibility ex ante and ex post facto HRV;

d. Giving broader access to remedies to affected by CHRV;

e. Raising awareness against CHRV.

As the common, civil and criminal laws have evolved from less clarity of the past to the common, strict civil and criminal laws of the presence, the time of shadow tCV and business laws to evolve into PtCV and more enhanced business laws has arrived. The need of such enhancement is prompted by the rapid globalization that has given to the TNC new vest opportunities for financial and all kinds of fraud; with the great power of capital access through lower interest financing and public investment. The rule of law should finally adjudicate corporate structures and thus establish fair market competition to benefiting the small and medium enterprises and investors, and preventing from CHRV and ICrC.

The U.N. Subcommission on Human Rights has created the Draft Norms: Transnational corporations and other business enterprises shall not engage in nor benefit from war crimes; crimes against humanity; genocide; torture; forced disappearance; forced or compulsory labor; hostage-taking; extrajudicial, summary or arbitrary executions; other violations of humanitarian law; and other international crimes against the human person as defined by international law, in particular human rights and humanitarian law.

The prevention or appropriate jurisprudence of CHRV could be done only if concrete data is collected worldwide about violations or complicity with violations done by TNC. However, an incomplete sometime vague system has been used to provide detailed reports. The Global Reporting Initiative (GRI), some NGO, and the States usually are the collectors of such information. Since after 2003 UN practice expressed by the SRSG and the PG finally accepted by the UN on June 16, 2011 is to request from the TNC to report their own violations.

The problem of companies focusing mostly (or even wholly) on positive examples in their reporting is quite common in relation to disclosure around human rights. A small number of noteworthy or innovative forms of human rights reporting have appeared outside of companies' corporate responsibility reports. They were examined as part of the reports analysis because they are relevant to the larger question of how companies report to their stakeholders on material human rights issues. ("Corporate Human Rights Reporting: An Analysis of Current Trends". Elizabeth Umlas 2009)

To consider corporate management to correct themselves under the public pressures or under such by the shareholders seems easy to achieve on a first side, however the facts speak differently:

- According to the Institutional Shareholders Services website, 108 "social responsibility" shareholder proposals were included in proxy statements during the spring season of 200737 - see the shareholder proposal chart attached hereto for an analysis of the social responsibility shareholder proposals included in proxy statements during 2006 and the spring season of 2007. The corporation omitted eight shareholder proposals, forty-seven were withdrawn by the shareholders, and fifty-one were voted on. Only two proposals were approved by shareholders. 
If States comply with these treaties and corporations are involved in human rights abuse, this does not constitute a breach of the treaty. In addition, none of the treaties contemplates the fact that some states place corporations within dangerously close proximity to human rights violations committed by states themselves. Corporations that may be linked to human rights violations suffer only reputational damage resulting from human rights infringements. Victims are left without any tangible remedies. International law in its present form is incapable of holding a corporation liable for the infringement of human rights. It also does not contemplate that corporations can be complicit in the carrying out of violations by states and vice versa.

An ambiguity of corporate legal personal liability has been perceived as an obstacle for imposing responsibilities upon corporations. Out of the common non-derogable human rights, e.g. any connection to the prohibition against retroactive criminal liability might be difficult to visualize.

In the aftermath of World War II, the United States Military Tribunal at Nuremberg in the I.G. Farben Trial treated the corporate defendant, Farben, as a legal entity, and the individuals managing the company capable of violating the laws of war. While the jurisdiction of the Criminal Tribunals for the former Yugoslavia and Rwanda is restricted to natural persons, the Rome Conference on the International Criminal Court (ICC) did not challenge the assumption that corporations are bound by international criminal law.

Theories of corporate criminal liability in use in domestic legal systems:

1) Identification: The basis for liability under the identification theory is that acts of certain natural persons are actually the acts of the corporation. The scope of liability is restricted to those who represent the corporation.

Alternatively, the unity of interest and ownership of the parent and subsidiary is so great that the subsidiary company is considered to legally have never existed or to have ceased to exist.

and

2) Imputation: Under the imputation theory, the corporation can be held responsible for the acts of all its agents.

In fact, in national legal systems, individual and corporate responsibilities are usually cumulative. This builds on the idea that the acts of employees or directors, when not performed in their "individual capacity", can be linked to the corporation.

An individual member of the executive board may be hence held liable if she/he have carried out an acts that substantially assisted or scientifically effected the furtherance of the goals of the enterprise, with the knowledge that his act or omissions facilitated the crimes committed through the enterprise in order to be criminally liable as a participant in a joint criminal enterprise. The International Criminal Tribunal for the former Yugoslavia (ICTY) was established on this legal basis by Security Council resolution 827. There are no reasons why the Special court for addressing the violations committed by transnational corporations could not be established in a similar way? Jernej Letnar Černič (2005).

Managerial accountability can also have a deterrent effect upon TNC fraudulent activities. Nevertheless, it might be that binding international regulation, directly aimed at corporations will prove necessary to overcome the shortcomings identified.

Finally, it is not like there is no adjudication of TNC human rights violations, it is the extend such jurisprudence takes place:

- In cases of ius cogens CHRV with gross CHRV infringements either directly or indirectly inflicted by TNC there is an international trend for adjudication, and under the pressure of UN, NGO and public opinion there is substantial progress achieved in pressing TNC in avoiding such by accepting corporate guides to prevent ius cogens CHRV. 
- However, in transnational cases of derogable CHRV the situation is much different, because of the ignorance toward such CHRV and difficulties to be proven in courts: neither International nor National Courts have the tools to pursue such cases. More alike a hands off approach for extraterritorial derogable CHRV is used. In the US and other AM the constantly evolving case and common national jurisprudence gradually limits such corporate derogable national CHRV infringements;

- However, as stated above the interdependence on globalizing markets that is becoming vital for economic and environmental coexistence the lack of protecting against social, environmental, and cultural CHRV is counterproductive at the least.

There is a close relation between CHRV and global development, environmental protection and terrorism. To establish a long-term balanced market development, to avoid recessions, to preserve Earth resources by expanding alternative energies, to prevent from global worming the CHRV ius cogens and derogable alike should be globally adjudicated. In addition, such adjudication relates limited liability corporate laws' ineptness under these new emerging conditions.

TNC are using their financial strength and the weakness of countries and markets to drag important issues for prevention of CHRV and WCC. Stabilization clauses are sometimes drafted so as to insulate investors from having to implement new environmental and social laws, or to provide investors with an opportunity to be compensated for compliance with such laws. Andrea Shember "Stabilization Clauses and Human Rights" IFC 2008.

\subsection{White-Collar Crime}

WCC is all included into $\mathrm{ICrC}$, however the last one includes general corporate crime and mens rea liability of advanced preventive jurisprudence that criminalize decision making and execution of $\mathrm{ICrC}$ ex ante and ex post facto in farther clearance of the inter alia those two. The $\mathrm{ICrC}$ is very much an aggregation of WCC and corporate crime on an international level being under adjudication taking the best from the US Federal Laws and Guidance and EU Laws, however, being much wider in jurisprudence because of the PtCV on the directors, officers, managers and employees involved in $\mathrm{ICrC}$ de lege lata by expressio unios.

Sutherland (1949: 9) defined white-collar crime as 'crime committed by a person of respectability and high social status in the course of his occupation. In 1981, the United States Department of Justice described white-collar crime as "[n]onviolent crime for financial gain committed by means of deception by persons whose occupational status is entrepreneurial, professional or semiprofessional and utilizing their special occupational skills and opportunities; also, nonviolent crime for financial gain utilizing deception and committed by anyone having special technical and professional knowledge of business and government, irrespective of the person's occupation.

A "white collar" prosecutor or defense attorney, for example, would more likely define "white collar crime" as crime that does not:

(a) Necessarily involve force against a person or property.

(b) Directly relate to the possession, sale, or distribution of narcotics.

(c) Directly relate to organized crime activities.

(d) Directly relate to such national policies as immigration, civil rights, and national security; or

(e) Directly involve "vice crimes" or the common theft of property.

White-collar crime could be categorized into:

1. OCCUPATIONAL
- INSIDER TRADING
- FRAUD
- EMBEZZLEMENT
- COMPUTER

2. CORPORATE CRIME

- VIOLATION OF LABOR LAWS 


\section{- PRICE FIXING}

- ANTITRUST VIOLATIONS

- FALSE ADVERTISING

- BLACK-MARKET ACTIVITIES

\section{POLITICAL CRIME}

The following violations are considered white-collar crimes: antitrust violations, bank fraud, bankruptcy fraud, bribery/ kickbacks, computer/internet fraud, consumer fraud, counterfeiting, credit card fraud, economic espionage and trade secret theft, embezzlement/larceny, extortion/blackmail, financial fraud, forgery, healthcare fraud, identity theft, public corruption, racketeering, and telemarketing fraud. Those in charge of the organization perpetrate e.g. unlike traditional embezzlement, which is usually committed by a low-level employee, collective embezzlement. It is a crime by the organization against the organization. The effect such could be very devastating not only on the individuals, but on the US economy, and consequently on the entire global marketplace. E.g. For the savings and loan crisis of the 1980s; collective embezzlement, or "looting" entailed the siphoning off funds for personal gain. This self-interested fraud has been shown to be the most costly category of thrift crime. As one high-ranking government official has noted. "The best way to rob a bank is to own one" United States Congress, House, Committee on Government Operations, Combating Fraud, Abuse and Misconduct in the Nation's Financial Institutions: Current Federal Reports are Inadequate. $72^{\text {nd }}$ report, 13 October 1989. The Report may be correct in that fraud did not cause the debacle, but the question remains as to its role in causing the massive losses that resulted. A study by Nobel economist George Akerlof and his colleague, Paul Romer found that deliberate insider looting of institutions accounted for 21 percent of government resolution costs, and that this was likely to be an underestimate. The estimated loss of equity in result of white-collar crime in the 1980s and Enron is about 400 Bullion USD.

However, it is still out in the open to be found the estimated losses inflicted to the global markets by the white-collar crime of 2001-07 Recessions, but sure, it should run in to the trillions USD.

One major misconception of white-collar crime is the notion that these crimes are non-violent and are committed by those who are non-violent in nature. (Richard G. Brody and Kent A. Kiehl 2010), Perri and Lichtenwald (2007, p. 18) have begun to link and examine this type of violent behavior and have coined the term red-collar crime. The organized crime gangs and 'disreputable business interests sometimes aligned with them' use 'corrupt political connections' to avoid fair economic competition, and that 'Organized crime now uses bribery as one of its primary tools to establish front companies aimed at gaining control of legitimate businesses and penetrating the legitimate economy' (Clinton's October 1995 Decision Directive No. 42 International Crime Control Strategy: $18,81)$.

Undisputedly, the organized crime is deeply engraved into corporate structures using the last for legalizing proceeds from criminal activities. E.g., after the 1999's market crush was published information that all Cosa Nostra Families had had serious presentation on the stock and financial markets thus defrauding millions from small and medium investors. The US government had begun to recognize that official corruption and organized crime feed off each other, and often work hand in glove. One of the many areas in which this is obvious is smuggling and trafficking; if it were not for corrupt border guards, customs officials, police and military officers, it would be much more difficult than it clearly is for criminal gangs to smuggle and traffic drugs, weapons and people. The Council of Europe's conference of Ministers of Justice that was convened in June 1997 and had as its theme 'Links between Corruption and Organized Crime' (Council of Europe website, visited August 2005). Various states and international organizations have begun to recognize the bilateral relationships between organized crime and terrorism and occasionally between these two phenomena and corruption; as one recent article expressed in (Engvall 2006: 836). 
A substantiated difference between white-collar crime and other general crime affecting human rights does not necessary apply. Not only the motives of both are the same as to appropriate someone's recourses or labor, and use someone for gain by using deception, but also the consequences are the same: for the preys to lose properties and some time financial and other freedom, and to be harmed mentally and physically. In addition, for the markets infiltrated by crime: to remain in constant restrains and underdevelopment, because of the negative consequences crime as a whole effect over consistent market development. (Corporate directors, officers, and employees mostly commit white-collar crime, while under "corporate" it is included the financial and market exchanges sectors.) A major characteristic of this area of crime is that prosecutions often follow a long history of offending. Financial frauds, for example, may have been continuing for years before discovery, tax evasion prosecutions are often for only selected offences for which evidence is available and safety or consumer prosecutions often follow a long history of warnings.

A priory neo-liberal economics conceptionally tolerates shadow particularly extraterritorial business environment; the law enforcement and the governments have considered white-color crime as a part of the society where shady business practices prompt economic growth ("honest" executives promising easy money on the public media and deceiving mostly seniors and the financially weak are good example of such practices). However, with the rapid globalization and rising productivity the business practices of shady practices have back-fired on markets by establishing market conditions of insecurity, and thus giving substantial advantage to the transnational corporations in comparison to the small and medium businesses. Hence are the advantages of the large market investors compare over the small and medium investors and of advanced markets compare over the emerging markets (China not included under EM). With the globalization the abilities of large corporations to jeopardize and exploit the international laws (that are very limitedly enforceable anyway) by moving production to markets with corrupted governments, exploring the limits of stabilization clauses, washing hands on the limited liability corporate laws, business laws and employment contract laws, and circumcising the existing anyway weak international human rights protection laws.

It should be noted that the current practice for prevention of international white-collar crime and human right violations focused on' home and host's States obligations in relation to rights and laws impacted by corporate activities, rather than on corporate entities as possible rights-holders. Ruggie, Gerald John 2007. Hence, it might be stated that the TNC complex structures of contractors and subcontractors, and of widespread expansion makes jurisprudence even more complicated particularly for emerging markets and markets in distress. With the exception of the US and partially the EU courts, many States avoid extraterritorial adjudication of TNC, through the WCC lengthy litigations and complicated procedures added by the limited liability corporate laws. The consequences of such lack of jurisprudence allow WCC to be considered as the most costly for the world crime.

Corporate crimes committed on all continents across a range of industrial activities in various sectors (e.g. chemicals, forestry, oil, mining, genetic engineering, nuclear, military, fishing, etc.) clearly point towards the need for greater control, monitoring and accountability of corporate activity in a globalized economy.

Extend Corporate Liability: Corporations must be held strictly liable without requirement of mens rea for any and all damage arising from any of their activities that cause environmental or property damage or personal injury, including site remediation. Parent companies as well as subsidiaries and affiliated local corporations must be held liable for compensation and restitution. Bhopal principles: ..... Corporations must bear cradle to grave responsibility for manufactured products. States must implement individual liability for directors and officers for actions or omissions of the corporation, including for those of subsidiaries...... Ensure Corporate Liability for Damage beyond National Jurisdictions. States must ensure that corporations are liable for injury to persons and damage to property, biological diversity and the environment beyond the limits of national jurisdiction, and to the global commons such as atmosphere and oceans. Liability must include responsibility for environmental cleanup and restoration. Greenpeace International ๑ August 2002 
Such behaviour is no less than criminal, and it is becoming increasingly difficult -sometimes impossible- to seek justice, and to hold these companies accountable and liable for their crimes.

\subsection{Economics of Crime}

Using a probit approach, Grogger (1998) shows that criminal activity rises when labor market conditions worsen.

"Vulnerable populations exist in every part of the world due to such factors as globalization, economic and political instability. As people become vulnerable to exploitation and businesses continually seek the lowest-cost labor sources, trafficking human beings generates profit and a market for human trafficking is created."

Several businesses along the manufacturing chain are at least partially dependent upon trafficked labor (Bales, 1999: 23-24; Bales, 2007: 126). At a low level, employers use trafficked labor for production in sweatshops, agriculture, and domestic labor. On the next level, producers subcontract jobs out to lower cost producers. A third level includes the intermediaries who obtain the goods from producers to supply to large corporations. At the top, international corporations demand the lowest priced goods for resale to consumers and to increase shareholder dividends (Bales, 1999: 9).

The fundamental reasons suggested by researchers for $\mathrm{CHRV}$ and $\mathrm{ICrC}$ have gradually changed from social to economic. Thus Globalization (Bales, 2005), Income differentials between developed and developing countries (Bales, 2000, 2003), Worldwide capitalism and transnational corporations (Anderson and Davidson, 2003). Universal devaluation and marginalization of women and children ((Demleitner, 2001). Ejalu (2006: 171-173) suggests poverty, lack of education, urbanization and centralization of educational and employment opportunities, cultural thinking and attitude, traditional practices, domestic violence, corruption, conflicts, and difficulty in acquiring visas as causes of human trafficking.

The motivations may be more complex as poverty can interact with population density, infant mortality, the percentage of children younger than 14, the level of the country's food production, the level of civil unrest, corruption in local governments, and cultural acceptance of trafficking (Logan et al., 2009) Worldwide conservative estimates are that more than two million children are affected with one million in Asian countries, hundreds of thousands in the former Soviet states and Eastern Europe, in addition to the more than one hundred thousand in the United States. The average age of children introduced to modern day commercial sexual exploitation is 13-14 but declining (Barnitz, 2001)

Some researchers have focused on the costs side and evaluated the deterrent effects of apprehension and penalization (Ehrlich 1973; Levitt 1997; Imai and Krishna 2004). Others have examined the relation between labor market and crime, concentrating on measures of the potential benefits of legal opportunities (see the literature reviews by Freeman, 1983, 1984, 1996, 1999). Among them, some have assessed the effect of wages on crime rates. Using aggregate data, Machin and Meghir (2004) for the UK (Kelly 2000; Fajnzylber, Lederman and Loayza 2002); these authors tend to show that more inequality is associated with higher crime rates.

To date the Inter-American System has not referred to the use of extraterritorial regulation to prevent overseas abuse by corporations based in a State party. The concept of corpus juris when addressing the issue of state responsibilities for business operations; and protection of economic, social, and cultural rights regarding business operations. Most empirical research on the economics of crime aims at testing the Becker hypothesis that the propensity to commit crime depends on the comparison of the expected costs and benefits of legal and illegal activities (Becker 1968; Ehrlich 1996). The Cairo Conference identified as causative factors for migration: "international economic imbalances, poverty, and environmental degradation, combined with the 
absence of peace and security, human rights violations and the varying degrees of development of judicial and democratic institutions".

\section{Markets and Crime}

Crime concentration arises in Verdier and Zenou (2004) because of locational segregation and racial inequality. The role played by labor mobility in shaping the spatial distribution of local crime enforcement activities and its impact on the allocation of crime.

An "occupational-choice" between becoming a worker or a criminal. It has been claimed in the literature that when the supply of criminals is endogenous, higher levels of enforcement that lead to the interdiction of criminals may generate an even larger pool of offenders. This effect is known as the "replacement" or "interdiction effect". "It deflects crime to other jurisdictions by making itself a harder target. There is a striking similarity between these results and what is observed in the literature on transnational terrorism (see Bandyopadhyay and Sandler, 2009, for example)"

Burdett et al. (2004) and Huang et al. (2004) develop equilibrium search models of crime to study the connection between crime and labor market opportunities.

An occupational choice between becoming a worker or a criminal. It is shown that when enforcement increases the number of criminals (due to the "replacement effect"), jurisdictions have an incentive to reduce their enforcement levels relative to the no-occupational choice case. Additionally, the equilibrium levels of enforcement are more likely to exceed the efficient levels in the presence of occupational choice.

A market's crime rate is thus considered a factor in the market's economic success. Much academic research examines the effects that of crime on the economic growth of local areas (Burhham et al., 2004; Greenbaum and Tita, 2004; Mauro and Carmeci, 2007). This research generally accepts that areas with higher crime rates experience lower rates of economic growth and development. Criminal behavior also depends on other cost comparisons, such as forgone wages and employment opportunities (Gould et al., 2002; Mocan and Bali, 2005; Corman and Mocan, 2000, 2005). The reasoning is that higher wages and employment opportunities decrease the attractiveness (by increasing the opportunity cost) of acquiring assets through criminal activity rather than through legal channels. A negative relationship between changes in the minimum wage and crime is expected, as the opportunity cost of committing a crime (forgone wage) increases as the real minimum wage increases.

It can be argued that an individual's cost-benefit calculation more often favors crime when his or her longer-run economic situation is considered, thus suggesting that changing economic conditions and deterrence levels may have a greater influence on city crime over long time horizons. At what point, both in duration and severity, do worsening economic conditions induce criminal activity.

Concentrations of clandestine workshops and enterprises are found in a number of European countries; they employ large numbers of illegal migrants and use labor practices that are contrary to the most rudimentary principles of respect for human rights are work. The migrants are often engaged through 'a bewildering array of subcontracting chains and agents', all of which can make it difficult to claim and safeguard basic human and labor rights. In extreme cases, their conditions and treatment can amount to forced labor. A recent study of the UK shows that these conditions are common to both regular and irregular migrants. (Stefanie Grant 2005)

"Child trafficking is an offence under international criminal law, and a violation of the child's human right not to be exploited economically" has been made obsolete by governments through the Convention on the Rights of the Child and the Trafficking Protocol. Nonetheless, trafficking of children takes place in many countries and regions of the world, involving an estimated at 1.2 million each year. 


\subsection{Employment and Crime}

In the cross-section dimension, crime and unemployment are positively associated. In model in which individuals are allowed to engage in both legitimate market activities and criminal behavior in order to assess the role of certain factors on the property crime rate. Increases in youth unemployment induce increases in crime. Unemployment effect is causal for burglaries, thefts, and drug offence. Violent crimes (threats, violence against police forces) are positively associated with unemployment. Unemployment has significant instantaneous effects on crime and crime has significant but lagged effects on unemployment. Cantor and Land (1985) Small differences in the probability of apprehension and in income inequality can generate quantitatively significant differences in the crime rates across similar environments. A $10 \%$ increase in income inequality causes a $54 \%$ increase in the crime rate. Where only the apprehension probability, $7 \boldsymbol{T}_{a}$, is increased by $10 \%$, we observe a $44 \%$ decline in the overall crime rate. A $10 \%$ increase in income inequality causes a $54 \%$ increase in the crime rate. On the other hand, a $10 \%$ increase in the fraction of individuals without a high school degree, $y_{1}$, causes a small decline in the crime rate, from $5.6 \%$ to $5.25 \%$, while a $10 \%$ increase in the apprehension probability reduces the crime rate by $43.4 \%$, a $10 \%$ increase in the duration of incarceration decreases the crime rate only by $15.5 \%$. Ayse Imrohoroglu, Antonio Merlo, and Peter Rupert (2006)

Becker (1968) and Stigler (1970). Becker (1968) The novelty of this approach is in its focus on economic reasons for criminal behavior as opposed to relying on personality traits that are special to criminals.

While poverty is a root cause of human trafficking, it is the lack of employment opportunities at home combined with a desire to seek out potential employment opportunities in other countries that helps create vulnerability to human trafficking. (The Nature of Human Trafficking, International Office of Migration, available at

http://www.iom.int/jahia/Jahia/pid/676, last accessed January 30, 2011)

Even when the risk of human trafficking is known, economic desperation drives people to take risks involving their personal safety. Sex trafficking and domestic labor trafficking in particular is driven by gender disparity, lack of education but most of all by a lack of viable employment. (Elizabeth A. Léon and Professor Connie de la Vega 2011)

\subsection{Globalization and International Crime}

The increase in movement between nations has lead to more opportunities for trafficking and exploitation. The extent of the problem has come to light and the plight of 27 million people enslaved worldwide has been recognized. $\mathrm{H}-2 \mathrm{~B}$ visa, are no different.....employers exercise excessive authority over their guest workers because they not only dictate the conditions of the work arrangement, but they also retain the ability to arbitrarily change the terms of employment previously established and confirmed with the workers. Bridget O'Riorda, 2010

The current Globalization of 2001-2007 Recessions has surrogated the increasing wealth gap, from one side: between rich and poor, in advanced markets, thus deteriorating the middle class and the increasing and from another side: devastating impoverishing of many emerging markets. Overall, the effect has been quite similar: the shrinking of the demand side of these markets consequently decreasing many governments' fiscal reserves thus prompting of rising national debt.

tCV and weak business laws have become a market obstacle for the small and medium enterprises (SME) and small and medium investors (SMI), which are put in unfair market competition under high interest lending in insecure markets environment of shady business. However, SME happen to be the expanding in importance employers (under these new conditions), which in order to maintain the needed market balance of demand-to-supply 
should be in a fair market competition with the TNC and Big Market Investors (BMI). Hence, under these current deteriorating market conditions not able to succeed and maintain consistent market expansion the high unemployment and underemployment has become imminent.

tCV does not only affect the lack of $\mathrm{ICrC}$ prevention and adjudication, but also it prompts and maintains the aggregation of crime in general by its inability of expanding balanced market demand. The 2007-09 recession was a consequence not only of deregulated and exacerbated Real Estate prices and easy crediting but also on the weakening market in the US as well in the most of the global markets, which did not allow investment diversification and concentrated specula into the very few mostly real estate parts of the markets. The small and medium investors (SMI), which did not have access to the expanding markets of China, India, and Germany because of the deregulated market exchanges of shady business, have mostly taken the negative effect of losing equity and capital and thus the circle of negative market shrinkage was exasperated. Hence, SMI loss of equity affects the small and medium enterprises (SME), which predominantly are their (SME) finance sources.

With a few beneficiaries as China and Germany, hence, with aggregated lack of fiscal reserves many other governments have been in odds with the rising needs for intervention to curtail rising unemployment, social and medical expenses, and infrastructural deterioration. The 2007-09 recession has had a devastating negative effect on many markets from AM like the US, UK and Italy (and now France) to emerging markets like Bulgaria, Romania and Greece. The Human Rights and International Crime have been flourishing under these deteriorating market conditions, bringing setback of Centuries of Human Rights improvement and success, the civilization is under threat as a whole indeed. The expansion of Gypsies from France, the State anti immigration laws in Arizona, the Wisconsin government limiting Unions and unionization are a few example, the imposed austerity measure by the EU on Bulgaria, Romania, etc, that affect the most on the bottom of the societies prompting mass discrimination and human rights abuses are the few.

\subsection{Corporate Liability imposed by the UN and other Organizations and Treaties}

General Comments from CESCR dealing with the right to work, the right to health, and the right to water specifically confirm the State's duty to protect against abuse by business enterprises . In fact, every CESCR General Comment since General Comment 12 on the right to adequate food in 1999 asserts, usually explicitly, that in order to fulfill the duty to protect States must regulate and adjudicate the acts of business enterprises. General Comments from the Committee on the Rights of the Child (CRC) also highlight that the State has ultimate responsibility for preventing abuse by the private sector, including business enterprises;

"Obligation to protect requires States parties to prevent third parties from interfering in any way with the enjoyment to the right to water. Third parties include individuals, groups, corporations and other entities as well as agents acting under their authority."

"The duties of States ... to control the marketing of medical equipment and medicines by third parties."

"Discourage production, marketing and consumption of tobacco, narcotics and other harmful substances."

"Enact or enforce laws to prevent the pollution of water, air and soil by extractive and manufacturing industries."

"Regulate or prohibit information on and marketing of substances such as alcohol and tobacco, particularly when it targets children and adolescents."

The State could violate the duty to protect if among other things it fails to regulate the activities of corporations; protect consumers and workers; 
The HRC said that States should "take the lead in implementing all measures necessary to eliminate discrimination against women in all fields, for example by prohibiting discrimination by private actors in areas such as employment, education, political activities and the provision of accommodation, goods and services."

States are obliged to regulate and adjudicate the acts of commercial companies to prevent abuse of rights enjoyed by indigenous peoples and to ensure effective remedies, including reparation, where necessary.

States should "encourage awareness among professionals of all media" regarding the need to avoid dissemination of prejudicial material and even recommends that States encourage selfmonitoring by the media, including codes of conduct to avoid racial discrimination or biased language.

The States, as appropriate, adopt measures "against public bodies, private companies and other associations that investigate the descent background of applicants for employment."

The HRC's General Comment 31 on the nature of the general legal obligation imposed on States parties to the Covenant, which contains strong wording about the duty to protect against violations by private persons or entities. It says that "the positive obligations on States Parties to ensure Covenant rights will only be fully discharged if individuals are protected by the State, not just against violations of Covenant rights by its agents, but also against acts committed by private persons or entities...

CESCR has said that States parties must prevent unreasonably high medicine, food and education costs resulting from protecting intellectual property. Products should be denied patentability where "commercialization would jeopardize the full realization" of other rights.

The States must regulate intellectual property rights holders (including those claiming rights as part of their participation in business enterprises) to protect other rights.

However, when issues before the treaty bodies involve activities related to business activity, Concluding Observations often contain general expressions of concern about such activities, rather than specifying whether or how States are expected to regulate or adjudicate the entities behind those activities.

While the treaty bodies rarely say expressly that States should regulate corporations to ensure respect for such special measures, it would seem difficult for States to implement such measures effectively without some form of regulation and adjudication.

Concluding Observations from CESCR in particular make it clear that States must investigate allegations of abuses by employers, suggesting that inspection mechanisms should not only have general monitoring functions but also the ability to investigate allegations and impose penalties on offenders.

There is less guidance from the treaties and the treaty body commentaries regarding whether the State may fulfill this duty by focusing on the acts of natural persons within the "offending" business enterprise or whether it is obliged to regulate and adjudicate the business enterprise in its own right.

While some treaties and their respective treaty bodies do not seem to express a preference for regulation or adjudication of legal persons as opposed to natural persons - or are inconclusive in this respect, newer treaties, in particular the OPSC to the CRC and the ICRMW, seem at a minimum to contemplate liability for business enterprises. For example, Art. 3(4) of the OPSC to the CRC provides that "subject to the provisions of its national law, each State Party shall take measures, where appropriate, to establish the liability of legal persons for offences established 
in paragraph 1 of the present article. Subject to the legal principles of the State Party, such liability of legal persons may be criminal, civil, or administrative." While this provision means that the required criminal penalties discussed in earlier paragraphs of Art. 3 may not apply to legal persons, the treaty at least recognizes liability for business enterprises, though it is clear that States have discretion in deciding how to establish such liability.

CRC has encouraged States to "extend liability" for those offences to "legal persons.

Further, in outlining measures required to combat trafficking, Art. 68(1)(b) of the ICRMW provides that such measures "shall include" imposing effective sanctions on "persons, groups or entities" involved, suggesting that States are encouraged to impose sanctions directly onto entities such as business enterprises assisting in illegal movements of migrant workers.

However, considering Art. 3(4)'s broad wording in relation to legal persons as described in Part II.D above, it is unclear whether the extraterritorial jurisdiction requirements above could require action in relation to legal persons. The Concluding Observations do not illuminate this issue. There are numerous references to States parties' duties to exercise extraterritorial jurisdiction under the OPSC but these relate to general principles affecting the effectiveness of such jurisdiction rather than discussing whether jurisdiction should be exercised over legal persons. In addition, while the Concluding Observations, which recommend that States extend their laws to legal persons, are encouraging, it is unclear if they were intended to relate to abuses committed by legal persons beyond the State's borders. (John G. Ruggie 2007)

\section{White Market \& Grey Market}

The size of the informal sector has been found to be associated with the tax burden (e.g., Cebula, 1997; Giles and Tedds, 2002), regulatory costs (Auriol and Warlters, 2005; Loayza, 2005); institutional quality and regulatory burden, in particular, of labor (Friedman et al., 2000, Johnson et al., 1997, 1998, 2000, Botero et al., 2004); and financial development (Straub, 2005). DablaNorris et al (2007) finds support for the significance of all of these constraints using a firm-level data set for a large number of countries. Our results provide evidence that however firms increase their formal operations with better enforcement quality, measured by a countrywide measure of rule of law, as well as by the firm's perception of the fairness of courts, and by fewer constraints in terms of anticompetitive practices and corruption. Both sales growth and the level of formality are negatively correlated to financial, and tax constraints, as well as to higher organized crime and anticompetitive practices. Era Dabla-Norris and Gabriela Inchauste WP/07/112

Shady market structures of the a priory in use economics is based on limited-liability corporate structures and weak business laws, which practices lower market security thus benefiting large transnational corporations, the Chinese government and the informal firms. The regulatory burden, legal quality, and efficiency of the formal sector are important determinants of informality in these countries, Era Dabla-Norris and Gabriela Inchauste WP/07/112. The biggest disadvantage under these conditions is to small and medium enterprises that should employee the largest percentage in any market advanced or emerging. There is direct causality between employment and crime, between low wages and crime, which most definitely works out its ways into human trafficking and national security. Economic considerations are therefore most likely to guide individual decisions of engaging in this type of criminal activities, Ayse Imrohoroglu, Antonio Merlo, and Peter Rupert (WP/05/02).

\section{Enhanced Corporate Liability to prevent from Human Rights Violations \& prompt International Corporate Crime Deterrence}

Referring to Fried, Frank, Harris, Shriver \& Jacobson LLP, 2007: "Currently, international human rights standards do not create binding legal obligations on U.S. corporations and state law fiduciary duty standards do not compel corporate Boards of Directors to act in furtherance of international human rights." There are two principal mechanisms in US for compelling corporate conduct: 
governmental action (through legislation and judicial enforcement) and shareholder action. In the United States, shareholders of a corporation can direct the Board of Directors to act through shareholder proposals. Accordingly, a shareholder group could initiate a shareholder proposal, to be presented to a vote of all of the shareholders, to compel the corporation to adhere to international human rights standards. Historically, however, corporate social responsibility proposals have not received widespread shareholder support. In the US civil proceedings, the corporation is not the only party that may be pursued. For example, in a standard securities-law civil suit, the defendants often include the corporation, its officers and directors, its accountants, its attorneys, and its underwriters. In criminal cases, it is more difficult to impose liability on third parties because of the mens rea requirements and the higher standard of proof. Corporate criminal liability has the potential to deflect criminal liability away from managers and on to the corporations themselves. There is case law upholding corporate convictions when all potentially liable agents have been acquitted. Although the legal rationales for this result are interesting, the important point is that these cases arise in the first place. That raises the possibility that liability deflection may occur. The deflection account is also recognized by prosecutors. The Department of Justice's Principles of Federal Prosecution of Business Organizations warn prosecutors to be cautious when engaging in plea negotiations with corporations, as those corporations may be willing to plead guilty to protect managers from liability. This concern may have led prosecutors to adopt policies designed to induce the corporation. Consequently, managers need to be compensated more than shareholders for bearing risk, which is likely to be reflected in a higher wage. That would lead firms to prefer to bear the risk themselves because that is cheaper than paying managers to bear it.

"At best minimalist and at worst ineffective in creating real accountability on the part of TNC for complicity in violations of human rights" Simons P. 2004

If we start with the notion that corporate wrongdoing is under-deterred, then we would want to argue for curtailing corporate criminal liability and increasing the focus on corporate civil liability and managerial liability.

The unsuccessful effort at the Rome Conference to subject "legal entities" to ICC jurisdiction. Whether to include criminal responsibility of legal entities. Eventually, was recognized that the issue could not be settled by consensus in Rome. Ref. ATS claims in Rasul v. Bush, 542 U.S. 466, 484-85 (2004) "In cases against private actors, such as corporations or individuals, courts must also consider whether the norm extends not merely to states, but also to the private actors." Justice Breyer, concurring, explained "The norm must extend liability to the type of perpetrator (e.g., a private actor) the plaintiff seeks to sue." This merely made explicit what should be obvious: corporations or their officers cannot be sued for violating norms that apply only to states, such as the international ban on individual acts of torture in peacetime." Judge Korman' argument comes down to the proposition that since international law does not impose criminal responsibility on corporations, and since U.S. courts rely on international criminal law to find a customary international law basis for ATS jurisdiction, there can be no ATS jurisdiction over corporate defendants.

Fiduciary Duties: Under Delaware law, the most significant state law governing U.S. corporations, there are two main fiduciary duties a director owes to a corporation, the duty of care and the duty of loyalty.

"Based on the current non-binding state of international law and well-established fiduciary duty principles, it appears that a claim against directors for a breach of fiduciary duty based solely on a corporate violation of international human rights standards (without a violation of law) is unlikely to succeed. On the other hand, it is unlikely that a claim against directors for breach of fiduciary duty for adopting a policy of adherence to international human rights standards would be successful". Fried, Frank, Harris, Shriver \& Jacobson LLP, 2007._Several widely ratified treaties in the last decade express a preference for States to impose criminal liability on corporations that aid and abet violations, but where that is not possible, require States at least to impose proportional civil or administrative liability. Doug Cassel (2008). 
Suggested in this paper is change of the Corporate Vail - Corporate Limited Liability Laws (CLL) by Piercing the Corporate Vail (PtCV) to Corporate Unlimited Liability Laws (CUL) that would apply not to the shareholders but to the board of directors and management. (In case, different corporations and corporate traditions practice different variations of the BOD involvement in dayto-day operations or even directional planning, which are managed by the Risk and other Corporate Management) Therefore, it is important to state in this paper that the change of the liability would be proper to apply to the decision-making process individuals and the executing these policies individuals, which actions consequence in Human Right Violations and International Corporate Crime rather than the Corporate Entities, which are only liable for allowing such individuals handsfree actions.

(1he

The UN and other international organizations' covenants imply in many occasions that the legal liability corporations and corporate individuals should bear when in human right violations MODEL PENAL CODE: OFFICIAL DRAFT AND EXPLANATORY NOTES 29-30, § 2.06 (1985):

Section 2.06. Liability for Conduct of Another; Complicity.

... (3) A person is an accomplice of another person in the commission of an offense if: (a) with the purpose of promoting or facilitating the commission of the offense, he ... (ii) aids or agrees or attempts to aid such other person in planning or committing it ...."

"Under the ICC Statute, while intent is required to aid and abet a crime committed by a single person (or a plurality of persons not forming a joint criminal enterprise) [under article 25(3)(c)], knowledge is sufficient to aid and abet a joint criminal enterprise [under article 25(3)(d)]." A. Reggio, Aiding and Abetting in International Criminal Law: The Responsibility of Corporate Agents and Businessmen For “Trading With The Enemy" of Mankind, 5 INT'L CRIM.L.REV. 623, 647 (2005).

See International Convention for the Suppression of Terrorist Bombings (1998), 8) (making criminally responsible anyone who, "(c) In any other way contributes to the commission of one or more offences as set forth in paragraph 1 or 2 of the present article by a group of persons acting with a common purpose; such contribution shall be intentional and either be made with the aim of furthering the general criminal activity or purpose of the group or be made in the knowledge of the intention of the group to commit the offence or offences concerned."

Articles 9 and 10 of the Nuremberg Charter allowed the International Military Tribunal to declare a "group or organization" criminal. In some cases, governmental bodies may also be sufficiently cohesive and criminal to qualify as "groups," so that corporate executives who knowingly assist them can be held criminally responsible for aiding and abetting. Doug Cassel (2008).

Convention Against Transnational Organized Crime, art. 10, Nov. 15, 2000, G.A. specifies that States must impose on the TNC participating in anyway into directly or in complicity abetting terrorism "effective, proportional, and dissuasive criminal or non-criminal sanctions, including monetary sanctions")

However, despite the legal ground covered by the international treaties and covenants some obstacles such as the $\mathrm{tCV}$ prevent their implementation, therefore a step in the right direction will be an effective unified PtCV jurisprudence that will enhance human rights prevention and jurisprudence. Hence, because of the recourse violations would have on the individual managers who either directly or by complicity not comply with the international human rights covenants and treaties, or commit ICrC. In addition, it will denationalize corporate adjudication instead of the currently used system thus it will expand the consequencual causation in fraudulent actions by corporate decision makers and thus it will reduce corporate inadequacy toward respect of human rights globally.

When shadow business laws obviously allow irresponsible managers and corporate officers to avoid the rule of law with limited sanctions, the strict business laws through imposing personal liability and better corporate accountability would reduce $\mathrm{ICrC}$ and CHRV. The history of the US Justice System has shown constantly improving adjudication i.d. is the best proof of adjuducational evolution, of from one side common laws, which have been constantly enhanced of clarity "ergo omnes" and practical implementation, and from another side the US society, which has been gradually adapting these laws and comprehending the powers of a lawful society. 
I do not see any reason for business entities to be allowed a shady market environment - easy business hurts the smaller corporations by limiting their access to lower interest rate financing as less secure and hurts the global marketplace development.

The coherent guess that $\mathrm{ICrC}$ would be reduced by these new actions relies on the experience of the most developed civil societies, which maintain higher than EM adjudications and respect to the rule of law. As stated in other sections of this paper AM have experienced gradual enhancement of the common and civil law, which aggregated by the public-health awareness and historical cultural conceptual anti-crime public attitude have brought such high anti-crime public comprehension. The analog between corporations and societies is imminent, thus if breaking of the law is not accepted and tolerated in societies, why corporate decision makers and managers doing so should be anyhow tolerated either? The UN SubCommission on the Working Methods and Activities of Transnational Corporations in August 2002, echoed these concerns stating, "only when binding standards are combined with the possibility of punitive sanctions for their violations can corporations be uniformly prevented from having a negative impact on the enjoyment of human rights"

In magnitude of capital and revenue some transnational corporations far overrun many countries and markets, so is their power to move and outsource production and services under the newly developed open global marketplace, therefore their abilities to bribe and influence laws and social developments are becoming "limitless". To rely on some kind of self-conciseness by the decision making and executive management cannot be considered coherent, while human rights violations in which corporate interest are the inflictors or in complacency are rising in percentages, especially after the last 2007-2007 recession. As the United Nations

Research Institute for Social Development (UNRISD) report warned, "There is a danger that corporate self-regulation, as well as various partnership arrangements, are weakening the role of national governments, trade unions and stronger forms of civil society activism. (See other sections of this paper).

Under the markets' growing role of intellectualization and intellectual property (in general, not only by legal definition), the stricter rule of law empowers the relevance of human capital. Thus, an enhanced corporate liability and rule of law, by this paper approach, will prompt positive markets environment to maintaining corporate long-term growth. "because wealth is now created by knowledge and other intangible assets such as skills and human capital that are more affected by Environmental Social and Corporate Governance concerns, rather than by land, factories, physical labor, or even finance capital". Thus, a better integration of social considerations into core business operations could yield significant competitive advantage, but that companies must tailor their efforts to exploit "a small number of initiatives whose social and business benefits are large and distinctive.", "that responsible and sustainable practices enable companies to effectively manage risks and create new business opportunities." (Harvard Business School' Prof. Michael Porter).

Proposals and adjudications:

(By Fried, Frank, Harris, Shriver \& Jacobson LLP, 2007)

- Adoption of a multilateral instrument specifying human rights obligations for corporations.

- Expansion of the Alien Tort Claims Act (28 U.S.C. \$1350 (2000)), which grants jurisdiction to federal courts over an alien for a tort committed in violation of the law of nations or a U.S. treaty, to cover a broader range of international human rights violations committed by private defendants.

- Adoption by individual governments of programs to incentivize international corporate social responsibility by offsetting the risk of enhanced liability through tax credits, insurance programs, legal assistance, purchasing preferences, and limitations on derivative suits.

"Managerial accountability can also have a deterrent effect (against HRV) upon TNC activities." Viljam Engström (2002) 
Alternatively, by the UK Companies Act 2006, which requires quoted companies to produce an annual "business review" for shareholders, including, "to the extent necessary for an understanding of the development, performance, or position of the company's business," information concerning environmental matters, and social and community issues, including information about company policies and their effectiveness?

Basically these suggestions and adjudications are enhancing preventive anti CHRV jurisprudence over the corporate entities and do not differ substantially from this paper, however the papers approach is very much simplified for jurisprudential implementation.

The ATCA has been evolving into international jurisprudence:

Doe v. Unocal (2004) established for the first time that multinational corporations may also be held liable for human rights violations when they are complicit in abuses committed by governments they are working with. This was also the first time that a multinational corporation was charged with complicity in rape as torture. While Doe v. Karadzic (1995) under the Alien Tort Statute (ATS), also known as the Alien Tort Claims Act (ATCA) that was the first time that a private person was held liable for violations of international law in U.S. courts and opened the door to extending accountability for human rights violations to other non-governmental entities.

However, a major setback is Khulumani v. Barclay Nat'l Bank Ltd., 504 F.3d 254 (2d Cir. 2007), aff'd for lack of quorum sub nom. American Isuzu Motors Inc. v. Lungisile Ntsebeza, 2008 U.S. LEXIS 3868 (May 12, 2008).

And the following cases lack quorum or are waved as forum non conveniens

- The list is generally taken from the January 2008 petition for certiorari by corporate defendants in the

South Africa apartheid litigation. Petition for a Writ of Certiorari at 23, n. 3, American Isuzu Motors Inc. v. Lungisile Ntsebeza, 2008 U.S. LEXIS 3868 (May 12, 2008) (affirming judgment below for lack of quorum)

- See Corrie v. Caterpillar, Inc., 403 F. Supp. 2d 1019 (W.D. Wash. 2005), aff'd on other grounds, 503 F.3d 974 (2007), and petition for reh'g filed, No. 05-36210 ( $9^{\text {th }}$ Cir. Oct. 9, 2007).

- Complaint If 2, at 459-99, Does v. Chiquita Brands Int'l, Inc., No. 07-CV-10300 (S.D.N.Y. Nov. 14, 2007).

- Complaint at 8-10, Mastafa v. Australian Wheat Bd., Ltd., No. 07-CIV-7955 (S.D.N.Y. Sept. 11, 2007).

- First Amended Complaint at 67-69, Mohamed v. Jeppesen Dataplan, Inc., No. 5:07-CV02798 (N.D. Cal. Aug. 1, 2007). See generally also David Weissbrodt \& Amy Bergquist, Extraordinary Rendition: A Human Rights Analysis, 19 HARV. HUM. RTS. J. 123 (2006) (discussing extraordinary rendition).

- Second Amended Complaint at 2, Xiaoning v. Yahoo! Inc., No. 07-CV-2151 (N.D. Cal. July 30, 2007) (case settled).

- Complaint I 49, Doe v. Drummond Co., No. 06-CV-61527 (S.D. Fla. Oct. 10, 2006) (case dismissed).

- First Amend. Complaint I 47, 172-177, Doe v. Wal-Mart Stores, Inc., No. $05-C V-7307$ (C.D. Cal. Dec. 28, 2005) (case dismissed; appeal pending).

- Complaint 9 9 35-37, Doe v. Nestle S.A., No. 05-CV-5133 (C.D.Cal. July 14, 2005)

In the US Federal Laws and many US States Laws there have been in some level PtCV relating Grossly Inadequate Capitalization: Were the assets put into the corporation very small in relation to the nature of the business of the corporation; Insolvency; Diversion of Funds; Disregard of Corporate Formalities; or Disregard of the Corporate Entity. Hence, in case of fraud the courts PtCV on mostly SME for plaintiffs seeking remedies. In addition, also PtCV in cases of very large corporate entities of major fraud e.g. Enron the court seek individual liability from directors, officers, and managers. In all the cases of PtCV by the Federal or State courts, the actions by the courts have been taken $\mathbf{e x}$ post facto. There is a requirement that the fraud or wrong result in an actual injury to the plaintiff. 
At present, corporations that operate extraterritorially cannot be held accountable for violation of international human rights standards under international law. Transnational and multinational corporations are under no direct obligation to respect, nor ensure respect, of human rights within their sphere of influence. While the UDHR is clearly a highly authoritative statement by UN member states, and establishes a model of expected moral behavior, it remains an unenforceable ideal in a world motivated by economic profit. Paula Richardson (2003)

Currently, the jurisdictional possibilities provided by international law for addressing human rights violations have however been restrictively used. In this respect civil liability has presented itself as an attractive alternative. This way political implication of the prosecuting government can be avoided. "However, even in this context difficult questions remain. Most notably, the utilization of this avenue becomes dependent upon the private international law of a state (and questions e.g. about choice of law, jurisdictional rules, forum non convenience interpretations, what level of corporate involvement is actionable, etc.)" Viljam Engström (2002).

The Executive limited liability causes a significant increase in a corporation's willingness to engage in risky behavior. Therefore, in PtCV scenario the ongoing natural process of adjudication of corporate human rights violations to corporate entities would be enhanced to personal adjudication beyond corporate entities onto the risk management and decision making corporate management. The individuals taking decisions for direct CHRV or complicit in such perpetrated by local contractors, governments or individuals under PtCV.

To assert individual the possible responsibility at the international level interest must be turned to international criminal law. Although the constitutive elements of this law are not completely unambiguous, it is held that individuals can be criminally responsible for certain violations of non derogable character (as mentioned above), however, it will be much easier to enhance corporate managers personal adjudication under PtCV by the ICC and ATCA, on a international level and by ECHR, CATSCA the California Transparency in Supply Chains Act of 2010 (Beginning on January 1, 2012, will require that certain retail sellers and manufacturers doing business in California disclose their efforts to eradicate slavery and human trafficking from their direct supply chain of tangible goods) and host states jurisprudence on national levels.

The US Federal Sentencing Guidelines (Ref. Mail and Wire Fraud, Securities Fraud and Obstruction of Justice) and the DOJ when ref. to corporate decision makers and managers fraud after the Enron case are careful not to break the whole company because of the negative impact such actions could have on stakeholders, employees, ext., thus the criminalization of individual conducts is imminent while the company as a whole might go under DPAs or NPAs. DOJ may have to consider whether criminal misconduct committed by an individual employee should be considered recidivism-for instance, one company official said that, at a large international company, it is possible that individual employees may engage in misconduct in violation of the company's compliance program, but this should not constitute recidivism on the part of the entire company. Overall, five of the seven companies and three of the five monitors with whom was discussed this issue reported that such a performance measure would be a useful way to measure the effectiveness of DPAs and NPAs. The conclusion that could be drawn from these procedures in use by the US prosecutors and judges and the effect of it is pretty much in harmony with the approach taken by this research suggesting a split of liability in which the fraudulent individual corporate decision makers and managers should be liable for their actions while the corporation as a whole even being in the hole for civil remedies and needed changes, in some occasions should not be in expressio unios with the individual violators under criminal jurisprudence follow mutatis mutandis.

Majority of ICrC and CHRV are contemporaneously consequencual on the perception of top-level officers and risk managers to impunity because of the corporate veil added by a pervasive corporate culture ("Machiavellian, narcissistic, prevaricating, pathologically optimistic, free from self-doubt and moral distractions," - see Ribstein, and risk-taking business executive. If the 
individuals who engaged in wrongdoing were influenced by this socially-destructive corporate culture, then relying only on criminal sanctions may not be effective in containing its effect, however, they would be much more cautious to break the law when they are personally liable. It is to believe that the world of shady business in a globalaizing marketplace brings an environment of "means justify the deeds", and many executive officers compromise their methods to maximize profits, so the fiduciary duties they have to the corporations should be extended to the rightsholders and the society as a whole. There should be no conflict of interests between corporate such and the human rights protection or anti-crime social efforts, and if there is, such it should be omitted with the prevailing social interests. The rational choice theory of motivation for law-abiding behavior depends upon the actor's realization that planned conduct might result in punishment. Unless individuals recognize that proposed conduct triggers criminal sanctions, they will not pause to evaluate the risk of detection and punishment. Even if they do pause to calculate such risks, judgment biases may impair that evaluation. The inherent difficulty of identifying fraudulent conduct affects the rational calculation made by corporate actors, who may accurately assess the chances of detection as slim. Yet if criminal penalties are increased enough to account for a low probability of detection, they are likely to reach unacceptable levels. The point is not to debate here the fairness issues inherent in increasing punishment as opposed to enforcement efforts, but merely to note another impediment to the rational-choice model. Taken together, the new behavioral theories and the problems regarding enforcement of white-collar crimes suggest greater attention be paid to the second theory of law-abiding behavior.

The social norm model, like the rational choice model, has inherent limitations that impede its effectiveness in encouraging law-abiding behavior. The commonly-held notion that it is difficult to instill moral values and ethical codes solely through law is supported by studies indicating that criminal law does not directly influence individual behavior. The effect of criminal law on individuals seems to be indirect and attenuated; at best, it influences and strengthens the norms of the social group, which individuals then internalize. In the end, criminal laws may have a greater impact on reinforcing behavior of the good citizen than changing behavior of the bad citizen. The criminal law is not, however, without influence on people. Criminal laws may indirectly influence individuals by confirming and maintaining existing values.

This notion emphasizes the significance of even-handed enforcement and interest-free, transparent legislation. If the system is viewed as morally credible and legitimate, individuals tend to obey the law in marginal situations when conduct is ambiguous or of borderline criminality. If people respect the criminal law system, they are likely to defer to the authority of the law even in the absence of a strong internalized norm. However, of course, criminal laws, or for that matter laws in general, are not the only influences on behavior.

CHRV could be brought before the ICC if extended to managerial responsibility (again in nonderogable offences). International criminal law does not address e.g. labor rights, whereas it presumably is within this category that more frequent instances of abuse can be found. While international criminal law (and individual responsibility) could serve to safeguard the most fundamental human rights, the protection this offers is radically different e.g. from the ambitions of voluntary initiative. Viljam Engström (2002).

In this paper is considered the change of PtCV as a fundamental change of approaches, which until now has come from outside-in i.e. from states or international community enforcing the jurisprudence in cases of CHRV in a foggy corporate jurisprudence to an inside-out i.e. from liable corporate individuals taking precautions to protect from being ex ante by mens rea or actus reus judicial action.

The evolution of international and national jurisprudence from non-derogable to derogable CHRV is a global public health question closely related to expanding poverty, environmental pollution, Earth resources exhaustion, crime, terrorism and shrinking market demand that consequently brings lack of employment and shrinking fiscal reserves for any market advanced and emerging. 
Hence, it will be a matter of time before jurisprudence covers more CHRV ground. Very similar if not the same effect such changes in approaches will affect the adjudication of WCC by helping to reduce WCC through imposing sanctions on corporate individuals mens rea or actus reus.

However, it is not about the adjudication of individual involved in CHRV and WCC as much it is about prevention from such by taking-off corporate decision makers and managers' impunity and immunity that is given to them by the corporate veil especially on a international ground.

$-$

The United Kingdom's Bribery Act 2010 is one example of a domestic measure that asserts extraterritorial jurisdiction over the actions of private actors abroad. The Dodd-Frank Wall Street Reform and Consumer Protection Act of 2010 ("the 2010 Act") which amended the 1934 Act was signed into law on July 21 2010. 'each resource extraction issuer to include in an annual report of the resource extraction issuer information relating to any payment made by the resource extraction issuer, a subsidiary of the resource extraction issuer, or an entity under the control of the resource extraction issuer, to a foreign government or the Federal Government for the purpose of the commercial development of oil, natural gas, or minerals including, i. the type and total amount of such payments made for each project of the resource extraction issuer relating to the commercial development of oil, natural gas, or minerals; and ii." the type and total amount of such payments made to each government"

The SEC does have the authority to bring civil and criminal prosecutions for failure to comply with its regulations. This recent US legislation is a compelling example of how domestic company law can foster an environment that encourages companies to comply with their duty to respect human rights.

The Consumer Protection from Unfair Trading Regulations 2008 ("the 2008 Regulations") are a good example, this United Kingdom legislation make it an offence for a trader to make a misleading omission as a result of which the average consumer makes a transaction decision that he would not otherwise have taken (s. 6 the 2008 Regulations). A misleading omission is defined as:

(1) A commercial practice is a misleading omission if, in its factual context, taking account of the matters in paragraph (2)

(a) the commercial practice omits material information,

(b) the commercial practice hides material information,

(c) the commercial practice provides material information in a manner which is unclear, unintelligible, ambiguous or untimely, or

d. the commercial practice fails to identify its commercial intent, unless this is already apparent from the context.

\subsection{Approaches for prevention of Crime}

Three categories for crime prevention and deterrence are considered by

1) the low enforcement;

2) the public health approach;

3) the consistent development of global markets.

The $1^{\text {st }}$ and $2^{\text {nd }}$ categories are mostly to deter crime in a short term when the $3^{\text {rd }}$ is to prevent crime in a long term by alienating the market conditions such as poverty, high unemployment and general lack of individuals' choice and thus improving the overall markets environment. This research equally exploits the $1^{\text {st }}, 2^{\text {nd }}$ and $3^{\text {rd }}$ categories for a more clear vision on how to reduce human rights violations and crime.

Growth in formal firms is negatively affected by both tax and financing constraints, while these constraints are insignificant for growth in informal firms. Moreover, formal firm growth improves with better enforcement as measured by fair and impartial courts, while informal firm growth is constrained by organized crime, pointing to their inability to take full advantage of the legal and judicial systems (Era Dabla-Norris and Gabriela Inchauste WP/07/112) 
Inter alia, girls' education, promotion of women's economic self-sufficiency, and job training. This also means that the president has discretion to choose to focus solely on granting NGOs funding to raise awareness. Although attainment of education and gainful employment is promoted as a necessary ingredient in prevention, to date there has been no comprehensive push to prioritize education and employment as a primary means of attacking the root cause of human trafficking. Jonathan Todres, The Importance of Realizing "Other Rights" to Prevent Sex Trafficking, 12 Cardozo J.L. \& Gender 885, 887-888 (2006)

The United Nations Office on Drugs and Crime (UNODC) has produced a Model Law that looks to the Palermo Protocol for influence. This model uses language that requires that state parties address prevention beyond media campaigns by attacking the underlying causes of trafficking through social and economic initiatives.

Brazil, China, and India have National Action Plans to Combat Trafficking of Persons, which ostensibly discuss prevention means, Russia is still way behind in even acknowledging prevention as a means to fight human trafficking. Strengthening human trafficking prevention programs by focusing on the right to education and the right to gainful employment not only decreases girls and women's vulnerability to traffickers but positively conflates with other gender equity goals including increased self-sufficiency, decreased gender-based violence, and decreased gender discrimination as well as contributing to broader goals such as increased access to health, peace building and economic development.

The UNODC has written a Model Law for states to adopt and provides prosecutors with toolkits specifically aimed at human trafficking. (UNODC on human trafficking and migrant smuggling). http://www.unodc.org/unodc/en/humantrafficking/index.html?ref=menuside

Of the older treaties, CEDAW is most explicit in referring to business by requiring States in Art. 2(e) to take all appropriate measures to eliminate discrimination against women by any enterprise. In relation to more recently adopted treaties, the Optional Protocol to the CRC on the Sale of Children, Child Prostitution and Child Pornography (OPSC), adopted in May 2000, requires States to prohibit practices such as the sale of children, child prostitution and child pornography, including taking action against "legal persons" where appropriate.

The ICRPD adopted in December 2006, is the most explicit and refers directly to both private enterprises and private entities. For example, Art.4 requires States parties "to take all appropriate measures to eliminate discrimination on the basis of disability by any person, organization, or private enterprise."

States have positive obligations to prevent and punish third party interference with the enjoyment of rights. Failure to abide by these obligations may amount to a violation of the State's treaty obligations. The duty to protect includes preventing corporations - both national and transnational, publicly or privately owned - from breaching rights and taking steps to punish them and provide reparation to victims when they do so. (Ruggie, Gerald John 2007)

Other stakeholders under a similar process often make the suggestion that they should be subject to suit to the investor-state arbitration. In the view of this author, such an approach is illusory, given the costs of international arbitration processes in many cases, and the difficulties in mounting such cases before tribunals designed for commercial law purposes rather than enforcement of legislation or obligations against corporations. (Howard Man 2008)

\section{Shrinking Markets effect on Human Rights and Crime}

"Poverty was also shown to play a role in sustaining wars, as crime and violence become the only viable livelihood strategy for the poor."

Goodhand, Jonathon. 2001 
The 2001\&07 Recessions have accelerated the processes of the widening wealth gap between rich and poor in the US and other Advanced Markets, and between the AM and EM. The decreasing industrial employment has been prompted by high technologies in manufacturing, the moving, and outsourcing of industrial production to China, India, Brazil ext., and the rapid industrialization of China itself. Contemporaneously causal of these market developments it has been the accumulation of substantial national debts for the last 20 years by most markets (with a very few exceptions of China). From Japan, the US and the UK to Greece, Spain and Italy markets are straggling to manage the slow marginal market growth with high unemployment resulting in reduced fiscal reserves, and many more as Bulgaria, Romania and pretty much the rest of the world are deepening in poverty and underdevelopment. The 2001\&07 Recessions have greatly affected these ongoing processes showing the restrained abilities under the used a priory economics somehow a substantial turn around to occur and longer term markets expansion to be achieved that could unleash the powers of the trickle-down economics and to offset the negative consequences inflicted by the recessions. With these negative market processes and the lack of deterrence and prevention, the human right violations and international corporate crime have increased disproportionately. The lack of fiscal reserves to expand the fight against human right violations and crime and the deepening poverty in many markets added to it. Joshua Konov (2011)

United Nations, Resolution adopted by the General Assembly on the report of the Third Committee (A/61/438, 30 January 2007)]

Recognizing also that women's poverty and lack of empowerment, as well as their marginalization resulting from their exclusion from social policies and from the benefits of sustainable development, can place them at increased risk of violence,

Recognizing further that violence against women impedes the social and economic development of communities and States, as well as the achievement of the internationally agreed development goals, including the Millennium Development Goals.

Thus the practiced relatively short-term deterrence achievable by the law enforcement or even the long term prevention achievable by public health approach and the eradication of poverty are both in a disarray as a consequence of the 2001\&07 recessions' negative market effect and I consider only way out a sufficient market expansion that could from one side replenish fiscal reserves, alleviate poverty worldwide and from another side PtCV on the corporate structures that will serve as a preventive method to CHRV and Corporate Crime.

The approach of separation the fight against human right violations and international crime from the need of improving and increasing global markets is incomprehensive and the effect of such (approach) is very limited indeed. A general market development is paramount that could establish employment choices and overall higher standard of life for many people around the glob.

The Globalization might have a very positive affect on the global market development and consequently on the HR and $\mathrm{ICrC}$, but the rules of the game must change from the "a priory" neoliberal shadow business environment into under the rule of law business environment. (Not founded on temporarily regulations and restrictions, which could be politically motivated and weighting on the business, but on corporate and business laws of justice and fair market competition). Here, I like to clear the definition of Shadow Economy that in compare to Prof. Axel Dreher more profiled definition that applies to any unofficial business activities, in this paper it is defined as the lack of liability, business, and contract laws of the official business, which affects market competition by lowering the market security to particularly SME and SMI, that under this new environment of rapid globalization and rising productivities (could be even called deindustrialization of markets) have become the major employers bound to maintain market development ("market development" changes "growth" too, as we see from the latest US and EU sluggish economic growth indicators). What the rule of law's enhancements might have on the AM and EM consistent market development is well-established in the Prof. Axel Dreher's (2002, 2003, and 2006) research that unless the business regulations and restrictions resist economic expansion the rule of law is positive for such. While under the currently practiced globalization "globalization promotes growth - but not to an extent necessary to reduce poverty on a large scale" 
Hence, if a consistent market development is succeeded, the general Human Rights (HR) situation should improve globally; the Human Trafficking, CHRV, Terrorism, and ext. should become morelike in the grip of the ICC and other institutions, because the aggregating poverty and rising inequality, which have been accelerated by the globalization and multiplied by the 2001-2007 Recessions require prompt actions of natural for the markets adjudication of TNC and enhancement of the business laws to reverse this process.

\section{Conclusion}

As disambiguated in this paper the hook over $\mathrm{CHRV}$ and $\mathrm{ICrC}$ is tightening progressively: courts and public pressure to fight against CHRV and $\mathrm{ICrC}$ are enhancing States and International jurisprudence. However, the CLL is a fundamental obstacle to reach the real CHRV perpetrators the corporate decision-makers (mens rea) and risk-managers (actus reus), because behind any corporation stay individuals making and executing decisions. The attempts of the UN and other $\mathrm{NGO}$ to fight CHRV and $\mathrm{ICrC}$ and take TNC to justice is a straggle against nationalism and powerful governments vigorously defending the TNC in their dealings abroad, which policies reflect IIAs and foreign policies greatly neglecting CHRV and ICrC. The pressure over States to enforce UN's HR covenants and anti-crime laws over TNC by extraterritorial jurisprudence is generally obscure, and only in que signifie ius cogens CHRV such jurisprudence is executed by some States and the International courts while in derogable CHRV including social, environmental and cultural human rights, and the right to justice, which (CHRV) in many cases affect millions around the world bringing poverty and injustice such jurisprudence is at the least poor. Therefore, I consider the implementation of Corporate Unlimited Liability Laws (CUL) as a step foreword to more fluent adjudication in cases of $\mathrm{CHRV}$ and $\mathrm{ICrC}$. Even farther, the CUL would become a preventive ex ante tool in addition to the ex post facto tools against CHRV and ICrC by shortening the path from such to the National and International courts' jurisdiction and jurisprudence. The UN HR covenants and the common and civil laws against HRV are very clear as stationeries and when becoming unilaterally enforceable the major improvement on a global scale could be well achieved.

\section{References}

1. Ayse Imrohoroglu, Antonio Merlo, and Peter Rupert, Understanding the Determinants of Crime, WP 06-02, 2006

2. Axel Dreher, Does Globalization Affect Growth?, First version: October 2002, This Version: January 2003

3. Axel Dreher \& Freidrich Schneider, Corruption and the Shadow Economy: An Emperical Analisis, WP 2006-01

4. Bridget O'Riorda, Migration and Debt Bondage: Manifestations and Policy Recommendations, University of San Diego - September 10, 201

5. Convention Against Transnational Organized Crime, art. 10, Nov. 15, 2000, G.A. res. 55/25, annex I, 55 U.N. GAOR Supp. (No. 49) at 44, U.N. Doc. A/45/49 (Vol. I) (2001)

6. Daniel R. Kahan, Shareholder Liability for Corporate Torts: A Historical Perspective, Georgetown University, A.B. 2006. $\odot 2009$

7. Doug Cassel Corporate Aiding and Abetting of Human Rights Violations: Confusion in the Courts, Copyright 2008 by Northwestern University School of Law Volume 6, Issue 2 (Spring 2008) Northwestern Journal of International Human Rights

8. Elizabeth Umlas, Corporate Human Rights Reporting: An Analysis of Current Trends, United Nations Global Compact, November 2009

9. Elizabeth M. Wheaton, Edward J. Schauer, and Thomas V. Galli Sex Trafficking into the United States: A Literature Review (2011)

10. Elizabeth A. Léon and Professor Connie de la Vega, Promoting Education and Employment for Women and Girls as Foundations, for Effective Human Trafficking_Prevention, Berkeley 2010 
11. Fried, Frank, Harris, Shriver \& Jacobson LLP, Trends in the Use of Corporate Law and Shareholder Activism to Increase Corporate Responsibility and Accountability for Human Rights1, 2007

12. Geraldine Szott Moohr, An Enron Lesson: The Modest Role of Criminal Law In Preventing Corporate Crime, Originally published at 55 FLA. L. REV. 937 (2003)

13. Goodhand, Jonathon. "Chronic Poverty and Conflict." Chronic Poverty Research Center. INTRACK 2001

14. Gagnon, Georgette et al. "Deconstructing Engagement. Corporate Self-Regulation in Conflict Zones," 53

15. J. Oloka-Onyango and Deepika Udagama, The Realization of Economic, Social and Cultural Rights: Globalization and its impact on the full enjoyment of human rights, preliminary report submitted by, , UN Doc. E/CN.4/Sub.2/2000/13 (2000

16. Jernej Letnar Černič, Crossing the Rubicon: Enforcing the international legal responsibility of transnational corporations for ius cogens human rights violations Master thesis 20 points Supervisor: prof. dr. Ineta Ziemele International Human Rights Law March 2005

17. Jonathan Todres, The Importance of Realizing "Other Rights" to Prevent Sex Trafficking, 12 Cardozo J.L. \& Gender 885, 887-888 (2006)

18. Joseph A. Grundfest, The Limited Future of Unlimited Liability: A Capital Markets Perspective, 102 YALE L.J. 387, 421 (1992)

19. Joshua Konov, "2001 \& 2007 Recession prompted Remaking of The International Organizations", Paper prepared for presentation at the PEIO, Philadelphia, PA USA, January 26-28, 2011 and also for publication in the Review of International Organizations. September 30, 2011

20. James H. Mittelman (ed.), Globalization: Critical Reflections, 1996, Lynne Rienner Publishers, 83-11

21. Michael J. Watt, RIGHTEOUS OIL? HUMAN RIGHTS, THE OIL COMPLEX AND CORPORATE SOCIAL RESPONSIBILITY, Copyright !c 2005 by Annual Reviews.

22. Ontario Human Rights Commissio AN INTERSECTIONAL APPROACH TO

23. DISCRIMINATION Addressing Multiple Grounds in Human Rights Claims Discussion Paper, 2002

24. Paula Richardso, Corporate Crime in a Globalized Economy An Examination of Corporate Legal Conundrum and Positive Prospects for Peace, September 2003

25. Panitch, Leo, "Rethinking the Role of the State"

26. Rabah Arezki and Markus Brückne, Rainfall, Financial Development, and Remittances: Evidence from Sub-Saharan Africa, WP/11/15

27. Ruggie, John Gerard International Regimes, Transactions, and Change: Embedded Liberalism in the Postwar Economic Order International Organization, Vol. 36, No. 2, International Regimes (Spring, 1982)

28. Ruggie, John Gerard State Responsibilities to Regulate and Adjudicate Corporate Activities under the United Nations' core Human Rights Treaties (12 February 2007)

29. Ruggie, John Gerard, 2007 "Business and Human Rights: The Evolving International Agenda." Corporate Social Responsibility Initiative, WP/31

30. Simons P. 2004. Corporate voluntarism and human rights. Ind. Relat. 59(1):101-4

31. Surya Deva, UN's Human Rights Norms for Transnational Corporations and Other Business Enterprises: An Imperfect Step in Right Direction University of Sydney, Year 2004 Paper 11

32. Stefanie Grant Harrison Grant Solicitor, International migration and human rights, The analysis provided in this paper is that of the author, and does not represent the views of the Global Commission on International Migration 2005

33. Thomas A. Garrett and Lesli S. Ott, City Business Cycles and Crime Working Paper 2008026B 
34. United Nations, Resolution adopted by the General Assembly [on the report of the Third Committee $(A / 61 / 438,30$ January 2007)

35. United Nations Human Rights Council (2009), "Business and Human Rights: Towards Operationalizing the 'Protect, Respect and Remedy' Framework," Report of the Special Representative of the Secretary-General on the issue of human rights and transnational corporations and other business enterprises, John Ruggie, Geneva

36. Viljam Engström, Who Is Responsible for Corporate Human Rights Violations?, Åbo Akademi University Institute for Human Rights January 2002

37. Vuyelwa Kuuya Corporate Complicity in Human Rights Violations A Discussion Paper , G\&J 2008

38. Veerl Van Den Eeckhout, Corporate Human Rights Violations and Private International Law, July, 2011 